\title{
Peripheral Mechanisms of Neuropathic Pain-The Role of Neuronal and Non-Neuronal Interactions and Their Implications for Topical Treatment of Neuropathic Pain
}

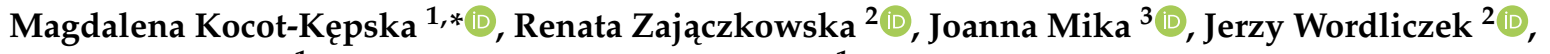 \\ Jan Dobrogowski ${ }^{1}$ and Anna Przeklasa-Muszyńska ${ }^{1}$ \\ 1 Department of Pain Research and Treatment, Medical College, Jagiellonian University, \\ 31-531 Krakow, Poland; jan.dobrogowski@uj.edu.pl (J.D.); a.przeklasa-muszynska@uj.edu.pl (A.P.-M.) \\ 2 Department of Interdisciplinary Intensive Care, Medical College, Jagiellonian University, \\ 30-688 Krakow, Poland; renata.zajaczkowska@uj.edu.pl (R.Z.); j.wordliczek@uj.edu.pl (J.W.) \\ 3 Maj Institute of Pharmacology, Polish Academy of Sciences, Department of Pain Pharmacology, \\ 31-343 Krakow, Poland; joamika@if-pan.krakow.pl \\ * Correspondence: magdalena.kocot-kepska@uj.edu.pl; Tel.: +48-12-4210885
}

check for updates

Citation: Kocot-Kępska, M.; Zajączkowska, R.; Mika, J.; Wordliczek, J.; Dobrogowski, J.; Przeklasa-Muszyńska, A. Peripheral Mechanisms of Neuropathic Pain-The Role of Neuronal and Non-Neuronal Interactions and Their Implications for Topical Treatment of Neuropathic Pain. Pharmaceuticals 2021, 14, 77. https://doi.org/ $10.3390 /$ ph14020077

Received: 16 December 2020

Accepted: 16 January 2021

Published: 20 January 2021

Publisher's Note: MDPI stays neutral with regard to jurisdictional claims in published maps and institutional affiliations.

Copyright: (c) 2021 by the authors. Licensee MDPI, Basel, Switzerland. This article is an open access article distributed under the terms and conditions of the Creative Commons Attribution (CC BY) license (https:/ / creativecommons.org/licenses/by/ $4.0 /)$.

\begin{abstract}
Neuropathic pain in humans arises as a consequence of injury or disease of somatosensory nervous system at peripheral or central level. Peripheral neuropathic pain is more common than central neuropathic pain, and is supposed to result from peripheral mechanisms, following nerve injury. The animal models of neuropathic pain show extensive functional and structural changes occurring in neuronal and non-neuronal cells in response to peripheral nerve injury. These pathological changes following damage lead to peripheral sensitization development, and subsequently to central sensitization initiation with spinal and supraspinal mechanism involved. The aim of this narrative review paper is to discuss the mechanisms engaged in peripheral neuropathic pain generation and maintenance, with special focus on the role of glial, immune, and epithelial cells in peripheral nociception. Based on the preclinical and clinical studies, interactions between neuronal and nonneuronal cells have been described, pointing out at the molecular/cellular underlying mechanisms of neuropathic pain, which might be potentially targeted by topical treatments in clinical practice. The modulation of the complex neuro-immuno-cutaneous interactions in the periphery represents a strategy for the development of new topical analgesics and their utilization in clinical settings.
\end{abstract}

Keywords: neuropathic pain; topical; ion channels; peripheral sensitization; pain management

\section{Introduction}

Neuropathic pain is defined by the International Association for the Study of Pain as pain caused by a lesion or disease of the somatosensory nervous system [1]. Neuropathic pain (NP) is not a particular disease, but the clinical condition that is caused by a variety of different diseases and lesions, injuring the nervous system at peripheral or central level, resulting in peripheral NP or central NP, respectively. The nerve damage and subsequent functional and structural neuroplasticity in sensory and autonomic nervous system, may become pathological and maladaptive in certain percentage of patients, and the risk of maladaptation depends on biological, genetic, demographic, and psychosocial factors [2]. The nerve damage induces extensive response in immune system as well, resulting in close interactions between nervous and immune system, and finally neuroinflammation. The functional and structural neuroplasticity and complex neuro-immune interactions result in inappropriate signaling from periphery, inappropriate modulation, and disturbed central processing of pain. In clinical practice, chronic neuropathic pain may be thus considered as neuro-immunological disorder with multiple neuronal and non-neuronal mechanism involved, either in periphery or centrally [3-5]. In humans, NP features may vary according to the location and character of the nervous system lesion, but it has been 
suggested that a more peripheral lesion induces more localized signs and symptoms of NP [6]. In 2010, the first definition of localized neuropathic pain was proposed, aiming at description of a special type of NP, which is caused primarily by the injury of peripheral nervous system. Localized neuropathic pain (LNP) is a type of neuropathic pain that is characterized by consistent and circumscribed area(s) of maximum pain, associated with negative or positive sensory signs and/or spontaneous symptoms characteristic of neuropathic pain [7], and is felt in superficial tissues [6]. In patients with LNP, complex peripheral mechanisms following nerve injury are suggested to generate and maintain pain and sensory abnormalities [8]. Thus, there is a rationale for use of topical analgesics, acting locally at peripheral level, which is in line with current principles in pain medicine pointing out at the need of personalized and mechanism-based approach to pain management [9]. Topically applied analgesics are supposed to target the underlying molecular/cellular mechanisms in the periphery only, without systemic mechanisms and site of action. The preclinical data support this idea, but, in clinical practice, only a few of peripheral mechanisms of NP are currently addressed [10-14] This review of literature is aimed at presenting the available evidence from preclinical and clinical studies on the peripheral mechanisms of NP with special focus on interactions between neuronal and non-neuronal cells, the molecular targets for topical analgesics, and clinical implications for topical administration in NP management. The current knowledge on complex mechanism of NP and possible molecular targets for analgesics administered by topical routes is crucial for health care professionals dealing with patients suffering from NP.

\section{Peripheral Mechanisms of NP}

\subsection{The Role of Neuronal Cells in Peripheral Mechanisms of NP}

Several hypotheses have been proposed to explain the complex processes of generation, maintenance of NP, and underlying mechanisms, but the pathophysiology of NP remains unclear, despite the huge progress made to date. It is known that the peripheral sensory neurons with the cell bodies located in the dorsal root ganglia conduct nociceptive information, which enters the spinal cord dorsal horn and then from the spinal projection is conveyed to supraspinal structures (such as the brainstem, thalamus, somatosensory cortex, insular cortex and anterior cingulate cortex) via ascending pathways [4,15-17]. In humans, peripheral somatosensory nervous system may become injured at several levels. There are multiple routes to its damage, including mechanical, thermal, chemical, and infectious factors. Peripheral nerve endings of pain-processing unmyelinated $C$ fibres and thinly myelinated A $\delta$ fibres may become injured by metabolic damage, toxins, medications, cytokines, and other inflammatory mediators. The axon may be damaged by trauma, compression, hypoxia, inflammation, overload, and chemical factors, and finally neurons in the DRG (dorsal root ganglion) may be exposed to several chemical and mechanical factors as well. Axonal and DRG damage may subsequently induce pathological and pain-promoting changes in peripheral autonomic nervous system $[18,19]$. In humans, the data regarding pathophysiologic mechanisms initiated after nerve injury is scarce. However, the common features of NP including spontaneous or evoked, burning, shooting pain, allodynia, hyperalgesia, or sensory loss, suggest likelihood of shared underlying pathology [17]. The more detailed data on NP pathophysiology comes from experimental animal models of NP. Peripheral mechanisms have been extensively studied in several animal models, such as spared nerve injury (SNI), chronic constriction injury (CCI), spinal nerve ligation (SNL), and specific disease-related neuropathies such as rodent models of diabetes, chemotherapy, herpes zoster, HIV (human immunodeficiency virus) induced peripheral neuropathy $[20,21]$. In animal models of NP after a peripheral nerve injury, independently of its character, extensive functional, structural, and molecular changes have been observed, either in damaged or neighbouring undamaged nociceptive neurons $(\mathrm{A} \delta, \mathrm{C})$, or either in peripheral nerve endings, along the axon or in DRG neurons [22]:

- peripheral fibre density changes-partial loss of peripheral innervation due to physical injury, chemical or metabolic neurotoxicity [23-25]; 
- fibre degeneration-axonal loss due to Wallerian degeneration (self-determined process leading to cytoskeletal destabilization and fragmentation) [25-28];

- peripheral sensitization-hyperexcitability of sensory neurons due to lowered threshold and augmented response to suprathreshold stimuli, caused by peripheral nerve or tissue injury, inflammation and subsequent release of pro-nociceptive mediators from mast cells, macrophages and from neighbouring nerve terminals, such as prostaglandins, bradykinin, histamine, serotonin, $\mathrm{SP}$ (substance $\mathrm{P}$ ), extracellular ATP (adenosine triphosphate), protons, cytokines, chemokines, growth factors, peptides, acting on corresponding receptors, ion channels or altering their sensitivity to stimuli $[8,29,30]$;

- $\quad$ ectopic firing in peripheral nerve endings and in DRG neurons-ectopic discharge begins in $A \delta$ fibres within hours after injury and within several days or weeks in C fibres [31-34]; the main generator of ectopic activity are hyperpolarization-activated and cyclic nucleotide-gated $(\mathrm{HCN})$ channels, belonging to the voltage-gated potassium (Kv) channels [35]; in human altered firing and ectopic activity in peripheral neurons was observed in patients holding a mutation in gene coding Nav1.7 [36];

- alterations in channel expression and composition in peripheral nerve endings, along the axon and in DRG - peripheral input via intracellular second messengers alters gene expressions, resulting in increase in protein expression of Nav (voltage-gated sodium channels), VGCC (voltage-gated calcium channels), TLR4 (toll-like receptors 4), TRP (transient receptor potential channels), $\alpha 1-\mathrm{AR}$ ( $\alpha 1$ adrenergic receptors), ASIC (acidsensing ion channels), decrease in protein expression of $\mathrm{Kv}$ (voltage-gated potassium channels) [37-40];

- $\quad$ synapse properties and locations of spinal terminals—sprouting of $A \beta$ fibres in spinal dorsal horn laminae [41,42];

- involvement of autonomic system-upregulation of $\alpha 1-\mathrm{AR}$ and enhanced adrenergic sensitivity at the injury site and in DRG neurons, sympathetic fibres sprouting in the periphery and in DRG [43-46].

It is worth mentioning that the pathological neuroplasticity after peripheral nerve injury in preclinical settings is seen not only in nociceptive $A \delta$ and $C$ fibres [8,47-49], but in the population of $A \beta$ fibres as well. $A \beta$ fibres respond normally to innocuous mechanical stimuli and in physiology are not involved directly in nociception. In animal models of $\mathrm{NP}, \mathrm{A} \beta$ fibres exhibited enhanced excitability, spontaneous activity, differences in action potential configuration and conduction velocity compared with control animals [50]. The data shows as well abnormal axonal sprouting of myelinated $A \beta$ axons in the spinal dorsal horn. The peripheral receptive fields of $A \beta$ neurons are more excitable, which in summary contributes to the generation and maintenance of the peripheral, central sensitization and NP $[42,51,52]$. The pathology in tactile $A \beta$ neurons, resulting in nociceptive responses to normally innocuous cutaneous stimuli, is observed in humans with NP and clinically refers to allodynia and spontaneous pain following peripheral nerve injury $[8,53,54]$.

The molecular processes involved in neuroinflammation and peripheral sensitization are presented on Figure 1 [8,22,29-40]. 


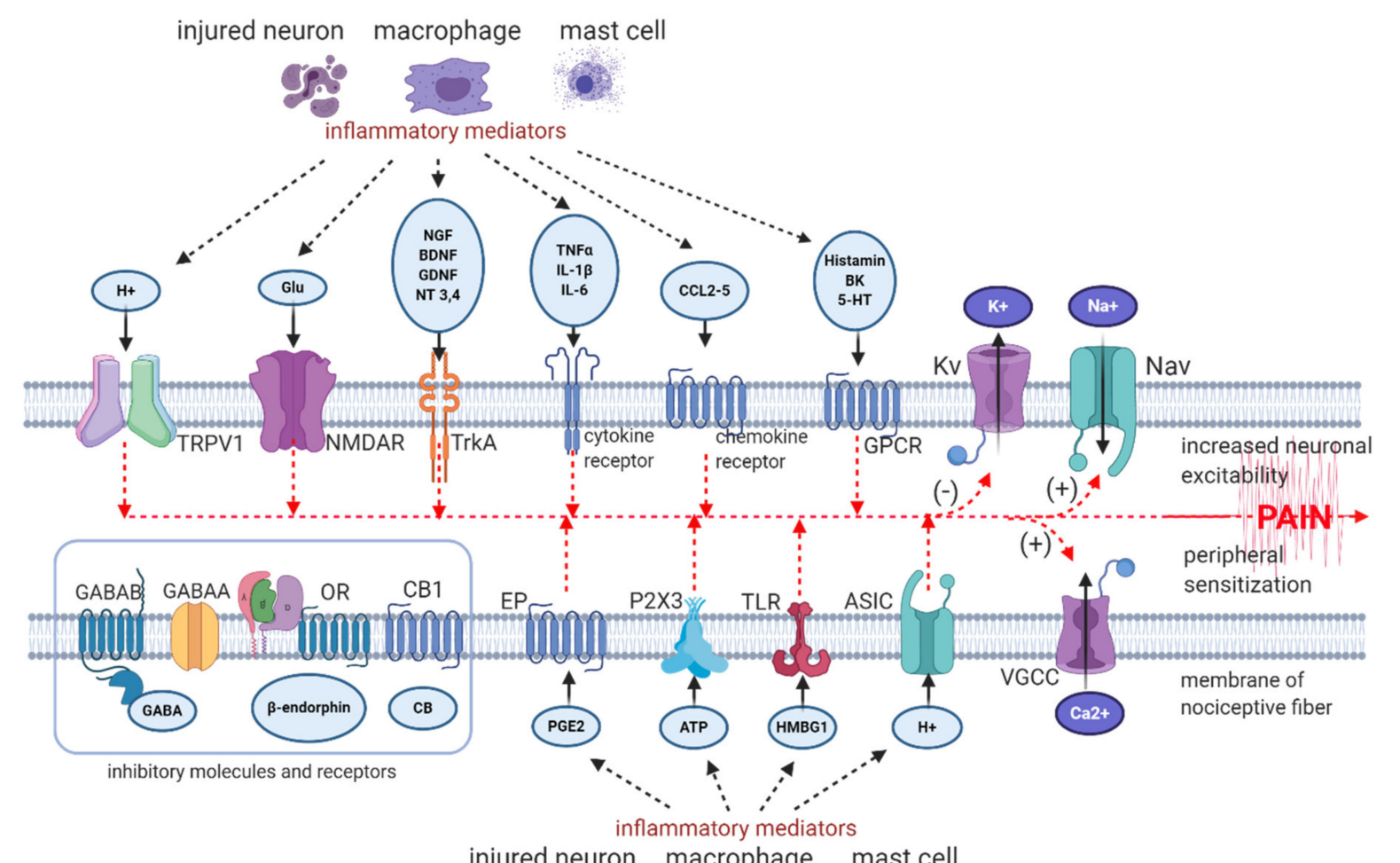

injured neuron macrophage mast cell

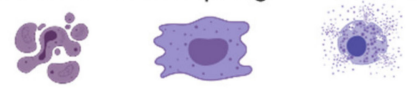

Figure 1. Neuronal ion channels, receptors and their ligands involved in peripheral neuroinflammation and sensitization. (-) Downregulation of $\mathrm{Kv}$ and $\mathrm{K}+$ currents, (+) upregulation of Nav, VGCC, and $\mathrm{Na}^{+}$and $\mathrm{Ca}^{2+}$ currents, respectively [8,22,29-40]. Abbreviations: Nav—voltage-gated sodium channel, TRPV1—transient receptor potential vanilloid 1 channel, VGCCvoltage-gated calcium channel, Glu—glutamate, $\mathrm{H}^{+}$-hydrogen proton, NMDAR-N-methyl-D-aspartate receptor, ASICacid sensing ion channel, TLR - toll-like receptor, P2X3-P2X purinoceptor 3, PGE2-prostaglandin E2, EP-prostaglandin E2 receptor, GABA—gamma-aminobutyric acid, GABAAR—gamma-aminobutyric acid receptor A, GABABR—gammaaminobutyric acid receptor $\mathrm{B}, \mathrm{Kv}$-voltage-gated potassium channel, OR-opioid receptor, $\mathrm{CB}$-cannabinoid, CB1— cannabinoid receptor type 1, HMBG1-high mobility group box 1 protein, TNF $\alpha$-tumour necrosis factor $\alpha$, IL-1 $\beta$ interleukin 1 $\beta$, IL-6-interleukin 6, CCL-CC-chemokine ligand, ATP—adenosine triphosphate, NGF-nerve growth factor, BDNF-brain-derived neurotrophic factor, GDNF-glial-derived neurotrophic factor, NT 3,4-neurotrophin 3 and 4, $\mathrm{Na}^{+}$-sodium ion, $\mathrm{Ca}^{2+}$ —calcium ion, $\mathrm{K}^{+}$- potassium ion, BK—bradykinin, 5-HT—serotonin, GPCR-G protein-coupled receptor. Created with BioRender.com.

\subsection{Role of Glial Activation in Peripheral Mechanisms of NP}

In animal models of NP after a nerve injury, extensive functional, structural, and molecular changes, parallel to that observed in neurons, have been seen in glial cells as well. Injury of peripheral nerve leads to significant activation of peripheral glia including Schwann cells in the nerve, satellite glial cells in DRG, and central glial cells including microglia and astrocytes in the spinal cord and brain. The involvement of other macroglia cells such as radial cells and oligodendrocytes in the nociceptive transmission has not been established to date $[55,56]$. After peripheral nerve injury, the activation of astrocytes in CNS (central nervous system) occurs about four days after microglial activation and persists until 12 weeks after damage, thus suggesting being involved in the persistence of pain [56]. Therefore, it is so important to silence the escalation of neuroimmune peripheral changes at an early stage by topical drug administration, which may reduce the risk of the development of central pain hypersensitivity. The glial activation includes proliferation, morphological changes, increased or de novo expression of cell membrane markers or receptors, and the synthesis of numerous mediators. Glial activation is a defensive mech- 
anism; however, it may malfunction after a nerve injury, leading to pain generation and its maintenance $[55,56]$. Schwann cells are most abundant glial cells in peripheral nervous system. They physically support long axons and produce numerous growth factors to nourish and myelinate axons, such as NGF (nerve growth factor), BDNF (brain-derived neurotrophic factor), GDNF (glial-derived neurotrophic factor), NT3 (neurotrophin 3) and NT4 (neurotrophin 4) [57]. Mounting evidence from preclinical studies suggests a key role of Schwann cells in peripheral NP states. After peripheral nerve injury, Schwann cells become activated, change their phenotype, proliferate, migrate, and release growth factors and other molecules promoting nerve regeneration. The role of growth factors in generation of NP has been confirmed in preclinical model, where the pain hypersensitivity resulted from release of BDNF from Schwann cells. The role of BDNF in NP has been further confirmed in BDNF-knockout mice, which displayed reduced pain behaviour compared to wild-type mice [58]. In NP conditions, multiple receptors and ion channels are expressed and upregulated on Schwann cells membrane: purinergic receptors, TLR, TRPA1 (transient receptor potential ankyrin 1), GABABR (gamma-aminobutyric acid receptor B), Ach (acetylcholine) receptors just to mention the most important in nociception. Exogenic molecules released from injured tissue, immune cells and neurons bind to corresponding receptors on Schwann cell membrane and via intracellular signalling promote release of growth factors, cytokines, and chemokines. The activation of Schwann cells results in the release of both proinflammatory cytokines (TNF $\alpha$-tumour necrosis factor $\alpha$, interleukin IL-1 $\beta$, IL-6) and anti-inflammatory cytokines (IL-10, Epo (erythropoietin)). Moreover, activated Schwann cells produce chemokines (CCL2-CC-chemokine ligand 2), growth factors (NGF, BDNF, GDNF, NT3, NT4), and messenger molecules (ATP), which together with cytokines can modulate nociceptive input [59]. Modulation of NP involve recruitment of immune cells to the site of injury as well. In model of sciatic nerve injury, axonal damage stimulates primary Schwann cells via TLR3 activation to release macrophage-recruiting chemokines (CC-chemokine ligands CCL2, CCL4 and CCL5) and subsequent macrophage recruitment to injured nerves [60]. Proinflammatory cytokines, mainly TNF $\alpha$, produced by activated Schwann cells and macrophages contribute to axonal damage and enhanced nociceptor activity. TNF $\alpha$ can alter the sensitivity of neurons to neurotransmitters via either increased activity and overexpression of neuronal ion channels, such as TRPV1 (transient receptor potential vanilloid type 1 ), AMPAR ( $\alpha$-amino-3-hydroxy-5-methyl-4-isoxazolepropionic acid receptor), VGCC, NMDAR (N-methyl-D-aspartate receptor), or down regulation of neuronal inhibitory GABA receptors [61]. Numerous receptors expressed and mediators released by Schwann cells in response to nerve injury, and data from preclinical studies confirmed direct interaction loop between activated neurons, Schwann cells, keratinocytes, and immune cells in the site of injury. Thereby, Schwann cells play a key role in regulating neuroinflammation and peripheral sensitization in NP conditions [55,56].

\subsection{Role of Immunocompetent Cells in Peripheral Mechanisms of NP}

Preclinical models of NP provide evidence for a substantial role of interactions between the nervous and immune system, resulting in neuroinflammation, altered sensory processing and evoked thermal and tactile hypersensitivity, but at the same time in damage repair as well [62] Among the immune cells, tissue-resident and recruited macrophages are supposed to play a key role in regulating neuroinflammation and peripheral NP [5,63,64]. Macrophages are plastic and may play opposite roles: proinflammatory M1 macrophages expressing proinflammatory cytokines (TNF $\alpha$, IL- $1 \beta$, IL-6, IL18), chemokines (CCL2-5) and toll-like receptors (TLR4), releasing ROS (reactive oxygen species), and anti-inflammatory M2 macrophages expressing anti-inflammatory cytokine IL-10 and chemokines CCL18, CCL22 and CCL24. In NP states, prolonged activation of M1 macrophages has been observed, which probably results from activation of TLR4 expressed on their cell membrane. In experimental animals, treatments directed at M1 macrophages reduced inflammation, pain behaviour in nerve injury and chemotherapy induced pain models [65,66]. 
Macrophages express $\alpha 1-\mathrm{AR}$ as well, and in preclinical studies activation of $\alpha 1-\mathrm{AR}$ by phenylephrine resulted in increased production of IL-1 $\beta$ in human monocytes and macrophages. On a cellular level, AR can modify cytokine production by macrophages by activation of TLR [67]. After injury, damaged neurons, Schwann cells, tissue-resident macrophages produce various cytokines, chemokines, and other signalling proteins, which recruit immunocompetent cells (macrophages, neutrophils, lymphocytes) to the injured site [68]. For example, in a model of a sciatic nerve crush injury, axonal damage stimulates Schwann cells to release macrophage-recruiting chemokines (CCL2, CCL4 and CCL5), resulting in macrophage recruitment to injured nerves [60] At the injured site, immune cells and Schwann cells release numerous proinflammatory cytokines (TNF $\alpha$, IL-1 $\beta$, IL-6), and chemokines (CCL2, CCL3, CCL4), acting on upregulated cytokine and chemokine receptors in peripheral nerve endings and DRG. The proinflammatory molecules via their receptors change the excitability, ion currents and second messenger systems of peripheral neurons, leading to peripheral sensitization and hyperalgesia. The cytokines may sensitize ion channels responsible for the transduction of stimuli (TRP_TRPA1, TRPV1, TRPV4) or alter the function of voltage-gated ion channels responsible for the regulation of the membrane potential (Nav, VGCC, Kv) [5,69-72]. Proinflammatory cytokines released from immune cells may increase the expression of alfa1-AR in keratinocytes and neurons, leading to local hyperalgesia in animal model of burn $[73,74]$. The expression of $\alpha 1-\mathrm{AR}$ on monocytes, macrophages, keratinocytes, and neuronal cells confirms that mediators of the neuroendocrine system (e.g., catecholamines) may modify neuroinflammatory responses. Further, it confirms the role of sympathetic system in NP generation and maintenance, suggesting a possible role of treatments addressing upregulated $\alpha 1-\mathrm{AR}$ in NP management [67]. Peripheral nerve injury induces Schwann cells and macrophages to release arachidonic acid and synthesis of its derivates, mainly prostaglandins (PGs) via COX-2 (cyclooxygenase-2) induction by cytokines. After an injury, PGs may be synthetized not only in recruited immune cells, but in neuronal cells as well. PGs regulate the function of peripheral sensory nerves in paracrine and autocrine manners in animal models on NP [75]. PGE2 (prostaglandin E2) via its EP receptor (prostaglandin E2 receptor), expressed in neuronal membrane, can modulate the excitability of peripheral nerve endings. PGE2 sensitizes ion channels and receptors (TRPV1, Nav1.7,1.8,1.9, VGCC, P2X3 (P2X purinoceptor 3)) and down regulates the Kv, which results in enhanced Na currents and Ca2+ influx, reduced $\mathrm{K}+$ currents, peripheral hyperexcitability and increased neurotransmitter release at the spinal level [76]. At the injury site, recruited macrophages interact with tissue-resident cells such as macrophages, mast cells and dendritic cells by releasing mediators such as CCL2, TNF $\alpha$, IL- $1 \alpha$, IL-1 $\beta$, and PGE, among others. These mediators act on corresponding receptors, expressed by immune cells and stimulate the release of cascade of pro- and antiinflammatory mediators, simultaneously enhancing further infiltration of immune cells to the site of injury. These interactions elicit long-lasting neuroinflammation and maintain the NP [5,77]. It is worth mentioning that immune cells express numerous receptors for ligands with potential inhibitory (anti-inflammatory or immunosuppressive) mechanisms of action. Macrophages, mast cells, microglia and other immune cells express CB2 (cannabinoid receptor type 2) receptor and OR (opioid receptor). In preclinical trials, it has been observed that agonists of CB2 receptor exert an anti-inflammatory effect, which might be potentially beneficial in chronic pain states [78]. In turn, in preclinical and clinical settings OR agonists such as morphine or fentanyl exerts immunosuppressive effect, resulting in reduction of either macrophage numbers or production of macrophage proinflammatory cytokines [79] Potentially, immune cells involved in peripheral neurogenic inflammation and their receptors may be target for topically applied cannabinoids or opioids [80-82]. Immune cells express GABA receptors and GABA as well. GABA agonist i.e., baclofen exerts an antipruritic mechanism in chronic dermatitis, but the role of interaction GABA receptor and its agonist in immune cells in NP is not confirmed [83,84]. Taken together, immunocompetent cells through their complex communication with Schwann cells, neurons and keratinocytes can induce local chronic neuroinflammation, ongoing keratinocyte, 
and peripheral nerve endings stimulation, which results in peripheral sensitization and NP. Potentially, immunocompetent cells involved in peripheral neuroinflammation and their receptors may be a target for topical treatments, acting on specific receptors, ion channels or enzymes (i.e., TLR, $\alpha 1-A R, C O X-2$, GABAR, CB, OR).

\subsection{The Role of Skin Cells in Peripheral Mechanisms of NP}

The idea of the neuro-immuno-cutaneous system (NICS), including peripheral sensory neurons, immune cells, and cutaneous cells, is becoming more recognized in clinical practice. The skin, besides being homeostatic and immunological barrier, acts as a sensory organ as well, since NICS is responsible for cutaneous sensations, such as touch, pressure, temperature, and pain. Sensory neurons are located in all layers of the skin: in the epidermis, dermis, and hypodermis. In the epidermis, the outermost layer of the skin, sensory nerve endings interact with other skin cells (keratinocytes and immune cells) in several ways, either via neurotransmitters, neuropeptides, and cytokines, or via membrane associations. The anatomical and functional interactions between neuronal and non-neuronal cells in the skin are contributing to nociception, neuronal hyperexcitability and peripheral sensitization $[85,86]$. The keratinocytes, which constitute $90 \%$ of epidermis cells, are one of the main targets of topically applied analgesics. The preclinical studies showed stimulation of keratinocytes alone to be sufficient to induce neuronal hyperexcitability and pain behaviour in animals $[87,88]$. According to preclinical data, keratinocytes express several receptors and ion channels, playing role in nociception, such as Nav (Nav 1.1,1.2, 1.5,1.6,1.7,1.8), TRP (TRPV1-4), neurokinin 1 receptor (NK1-receptor, NK1R), TLR, interleukin receptors, $\alpha 1-\mathrm{AR}$, endothelin1 receptors (ET1), calcitonin receptor-like receptor (CRLR), CB receptors, OR, NOP (nociceptin-orphanin opioid peptide) receptors (NOP-R), VGCC, NMDAR, and GABAR to mention a few [89-96]. The role of keratinocyte receptors and their overexpression in nociception has been confirmed in clinical observations. In patients with small fibre neuropathy a statistically significant increase of TRPV1 expression on epidermal keratinocytes was reported [97] The skin biopsies from patients with complex regional pain syndrome (CRPS) or postherpetic neuralgia (PHN) were analysed, and the samples exhibited Nav1.1, Nav1.2, Nav1.5, Nav1.6, and Nav1.7 and Nav1.8 immunolabeling, which was not present in normal skin [91]. Besides expressing numerous receptors and ion channels, in physiological conditions, keratinocytes can synthesize several neuropeptides, neurotransmitters, such as SP, calcitonin gene-related peptide (CGRP), ATP, Ach, glutamate, various growth factors, cytokines, chemokines, and many other autacoids, which modulate via corresponding receptors the function of neighbouring neuronal and immune cells $[85,94]$. After peripheral nerve injury, the synthesis and release of excitatory factors by keratinocytes may be enhanced via Nav activation. Stimulated keratinocytes produce factors, such as SP, CGRP, ATP, and PG that in turn bind to or sensitize receptors on peripheral nerve endings, resulting in depolarization [11,91]. The keratinocytes may express the modulatory analgesic properties as well. For instance, CB2 activation by cannabinoid and noncannabinoid cannabis compounds, such as $\beta$-caryophyllene and tetracyclic triterpene euphol, leads to the local release of endogenous opioid $\beta$-endorphin from keratinocytes [98-100]. The data from clinical and preclinical data confirm the role of keratinocytes in nociception, either in transduction or peripheral modulation of nociceptive input. Theoretically, the receptors and ion channels expressed by keratinocytes and involved in nociception may be targeted by topically administered analgesics, to reduce hyperactivity and release of pronociceptive molecules from skin cells [11-14,101].

\subsection{Peripheral NP as the Result of Neuronal and Non-Neuronal Mechanisms}

The functional, structural, and molecular changes induced by peripheral nerve injury occur not only in neurons (both sensory and autonomic) and glial cells, but in non-neuronal cells (keratinocytes; immunocompetent cells-macrophages, mast cells, neutrophils), participating in modulating sensory transduction in the periphery, which have been characterized in several preclinical models $[28,56,59,62,64,86,87,101-103]$. Upon physiological conditions, 
neuronal and non-neuronal cells in the periphery create a complex interplay on Figure 2, interacting by each other by released neuropeptides, cytokines, and neurotransmitters, acting on corresponding ion channels and receptors. Upon NP conditions, the loop of interactions become overactive and leads to inappropriate sensitivity and functioning of neuronal and non-neuronal cells, resulting finally in hyperexcitability of nociceptors and disturbed signalling from periphery to second-order neurons at spinal level, with several faults either in transduction or transmission. Inappropriate signalling and pain processing result in pain and sensory abnormalities, characteristic for NP such as allodynia and hyperalgesia, which may arise from three neuronal mechanisms [8]:

- peripheral sensitization-hypersensitivity of primary afferent nociceptors;

- central sensitization-increased responsiveness of nociceptive neurons in the CNS to their normal or subthreshold afferent input;

- a switch in the messaging of $\mathrm{A} \beta$ fibers from tactile to nociceptive input.

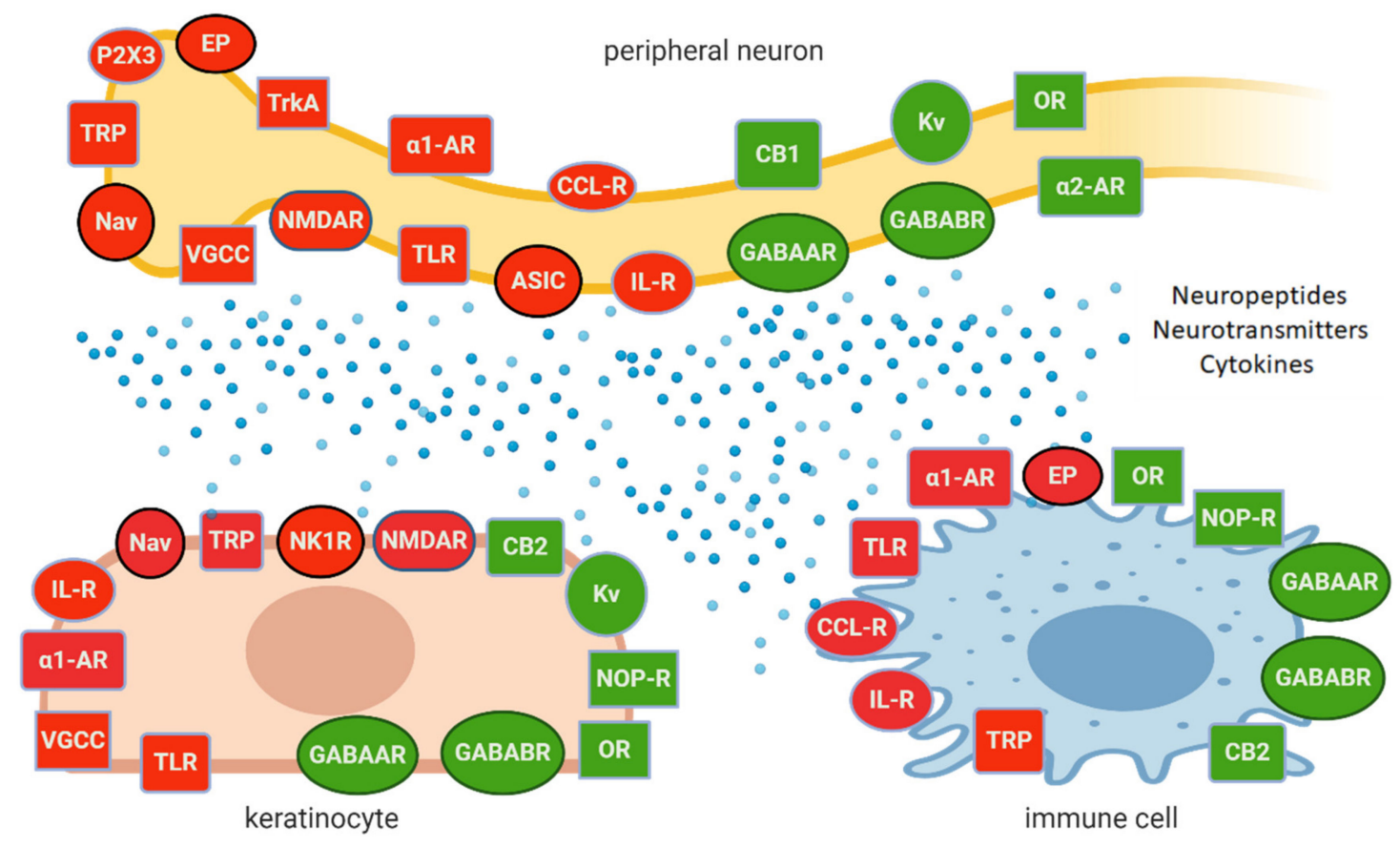

Figure 2. Complex interplay of peripheral neurons, keratinocytes, and immune cells; expressing excitatory (in red) or inhibitory (in green) ion channels or receptors, involved in pain generation, modulation, and maintenance, which potentially may be a target for topical treatments. Abbreviations: Nav-voltage-gated sodium channel, TRP-transient receptor potential channel, VGCC — voltage-gated calcium channel, NMDAR-N-methyl-D-aspartate receptor, ASIC—acid-sensing ion channel, TLR - toll-like receptor, $\alpha 1-\mathrm{AR}-\alpha 1$ adreno receptor, $\alpha 2-\mathrm{AR}-\alpha 2$ adreno receptor, EP-prostaglandin $\mathrm{E} 2$ receptor, GABAAR — gamma-aminobutyric acid receptor A, GABABR - gamma-aminobutyric acid receptor B, $\mathrm{Kv}$-voltage-gated potassium channel, OR-opioid receptor, CB1, CB2-cannabinoid receptor type 1 or 2, NOP-R-nociceptin receptor, CCL$\mathrm{R}$-chemokine receptor, IL-R-interleukin receptor, TrkA-Tropomyosin receptor kinase A, NK1R-neurokinin 1 receptor. Created with BioRender.com.

Clinical studies suggest that mechanisms like that observed in preclinical models may also be involved in humans with NP [8]. However, the fundamental question is whether $\mathrm{NP}$, following peripheral nerve injury, is maintained by pathological input from periphery or by central (spinal and supraspinal) generators (centralized pain). It has been confirmed in preclinical trials that hyperexcitable primary afferent neurons ("irritable nociceptors") and their pathological functioning may induce similar hyperexcitability within the CNS, leading to amplification of incoming peripheral pathological input, maintenance, and aggravation of central sensitization $[8,17,104]$. 
Preclinical studies have provided evidence that the early response to peripheral nerve injury in the DRG is driven by macrophages, lymphocytes, and satellite cells, and this is followed by activation of spinal neuronal and glial cells [56]. During the last decade scientists began to formulate new ideas on activated glial cells involvement in synaptic plasticity and signal transduction. This idea is supported by the fact, that neurons and glial cells express on their membranes similar receptors, ion channels, transporters, as well as share similar second messenger systems of intracellular signals. Therefore, pharmacological inhibition of peripheral sensitization can, as consequence, prevent, diminish, and/or cure the central sensitization. The confirmation comes from clinical observations, published by Haroutounian et al. [19] and Gracely et al. [105], who reported reduction in spontaneous pain and allodynia after a peripheral nerve block with lidocaine in patients with NP. Therefore, the data suggests that central sensitization after peripheral nerve injury may be partially maintained by peripheral hyperexcitation and ongoing electrical discharge in sensory neurons. It is reasonable to argue that pathological activity in primary afferent fibres is crucial for NP development $[8,19,32,50]$.

\section{Topical Administration of Analgesics in LNP}

The concept of topical administration of analgesics in LNP emerged from preclinical and clinical trials, where it has been confirmed that:

- input from hyperexcitable primary afferent fibres plays significant role in development and maintenance of NP at the spinal and supraspinal level $[8,19,50]$;

- peripheral neurons exert complex interactions with glial cells, immunocompetent cells, and keratinocytes, contributing to peripheral sensitization and neuronal hyperexcitability on Figure $2[8,59,86]$;

- inhibition of peripheral sensitization can diminish and/or eliminate the signs and symptoms of central sensitization $[19,105]$.

Preclinical studies confirmed the role of several ion channels, receptors, enzymes, neurotransmitters, neuropeptides, cytokines and other signalling molecules in peripheral sensitization, inappropriate signalling from periphery and NP behaviour. Evidence for the peripheral mechanisms and their role in NP comes from clinical trials and observations as well, however only a few mechanisms have been directly confirmed in humans:

- role of Nav:

- in humans with primary erythromelalgia altered firing and ectopic activity in peripheral neurons was observed due to the mutation in gene coding Nav1.7 [36];

- gain-of-function mutation in Nav1.7, Nav1.8 or Nav1.9 coding genes was associated with small fibre neuropathy and other neuropathic and non-neuropathic pain syndromes [106];

- loss-of-function mutation in gene coding Nav1.7 or Nav1.9 results in congenital insensitivity to pain [106];

- $\quad$ increased Nav1.1, Nav1.2, Nav1.5, Nav1.6, Nav1.7 and Nav1.8 expression in the skin of patients with complex regional pain syndrome (CRPS) or postherpetic neuralgia (PHN) [91];

- role of $\alpha 1-\mathrm{AR}$-in patients with CRPS $\alpha 1$-AR are upregulated in the epidermis and on dermal nerve fibres [107], activation of $\alpha 1-A R$ on human macrophages results in enhanced synthesis of IL-1 $\beta$ [67];

- $\quad$ role of TRPV1-in patients with small fibre neuropathy a statistically significant increase of TRPV1 expression on epidermal keratinocytes was reported [97];

- $\quad$ SNAP-25 (synaptosome-associated protein 25) — plasma membrane protein forming the SNARE (SNAP-receptor), involved in synaptic vesicle fusions, exocytosis, and neurotransmission. SNAP-25 modulates VGCC protein expressed on plasma membrane. Abnormal expression or function of SNAP-25 are observed in chronic pain conditions, including neuropathic pain and fibromyalgia [108]. 
Although only a few molecular/cellular mechanisms of NP in humans have been directly confirmed, the preclinical and clinical data support the idea of topical administration of analgesics with different mechanisms of action. Active molecules from topically applied treatments diffuse across the stratum corneum and then penetrate to some extent into the deeper skin layers, where their effect is expected. The molecules of topical drugs act on several distinct ion channels, receptors, or enzymes expressed by either neuronal or non-neuronal cells (Figure 2). The result of this process is the interruption of mutually intensifying stimulation loops, reduction of peripheral sensitization, peripheral input, hyperalgesia, allodynia, and finally reduction of pain intensity in patients with LNP (Figure 3).

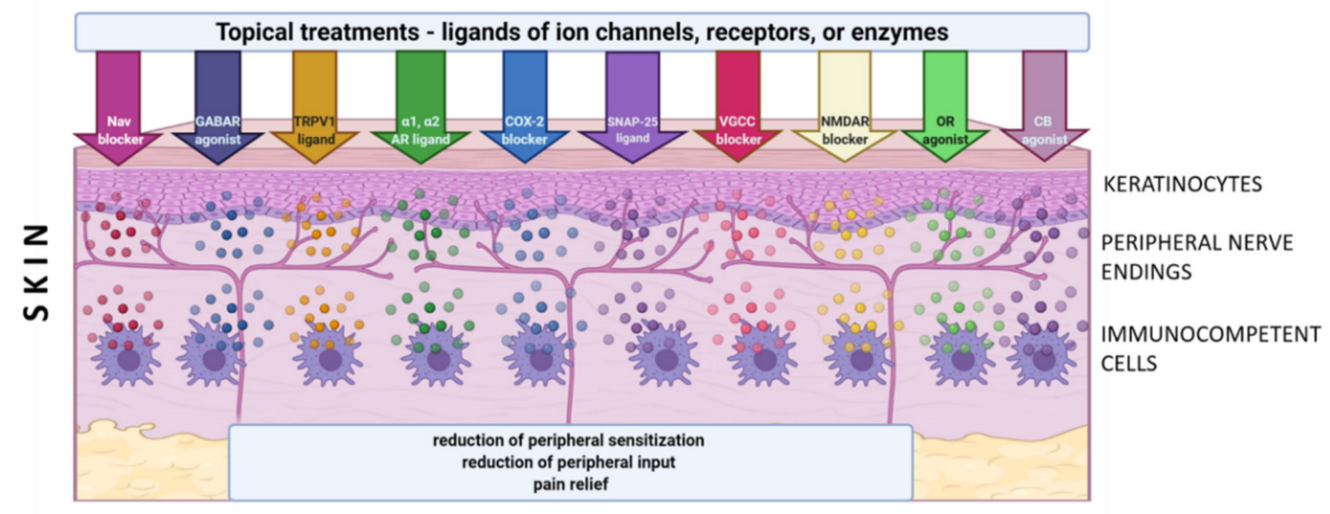

Figure 3. Topical treatments utilized in clinical practice in patients suffering from neuropathic and/or inflammatory pain, and their suggested molecular/cellular targets. Abbreviations: Nav—voltage-gated sodium channels, TRPV1—transient receptor potential vanilloid 1, VGCC — voltage-gated calcium channels, NMDAR-N-methyl-D-aspartate receptors, $\alpha 1$ $A R-\alpha 1$ adreno receptors, $\alpha 2-A R-\alpha 2$ adreno receptors, GABAR—gamma-aminobutyric acid receptors, OR—opioid receptors, CB- cannabinoid receptors, COX-2—cyclooxygenase 2, SNAP-25—synaptosome-associated protein 25 . Created with BioRender.com.

The concept of topical treatments is in line with current theory of mechanism-oriented pain treatment; therefore, they might improve the quality of pain management and patients' satisfaction with the treatment [9]. According to clinical data, most studied topical treatments (i.e., $5 \%$ lidocaine patch, $8 \%$ capsaicin patch, BTX-A (botulinum toxin A) in subcutaneous injection) have comparable analgesic efficacy in patients with NP, but relatively few systemic side effects and drug-drug interactions compared to systemic drugs. However, according to systematic reviews, topical drugs still have a weak recommendation for use in patients with LNP $[109,110]$. In clinical practice, numerous other agents have been used topically in patients with LNP, such as capsaicin at low concentration, antidepressants (amitriptyline, doxepin), antiepileptics (phenytoin, baclofen, gabapentin), ketamine, ambroxol, prazosin, clonidine, opioids (loperamide, morphine), cannabinoids (palmitoylethanolamide, cannabidiol), NSAIDs (nonsteroidal anti-inflammatory drugs) (diclofenac, ibuprofen, ketoprofen), blockers of Nav 1.7 (TV-45070). However, evidence on their efficacy in LNP is inconsistent or inconclusive, therefore they are not included in clinical recommendations $[109,110]$. In the literature there are numerous preclinical trials pointing out at antinociceptive effect of substances administered topically in animal models of inflammatory and NP. They are not utilized in clinical practice yet and therefore not included in this review [111,112]. Tables 1 and 2 present the most studied and suggested mechanisms of action of topical treatments, being used in clinical practice.

Topical drugs utilized in subjects with LNP exert multiple mechanisms of action, but which ones are most crucial and responsible for analgesic effect observed in humans has not been fully elucidated. Given that interactions between neuronal and non-neuronal cells involve multiple mediators and broad spectrum of receptors, single agents targeting multiple mechanisms or combination of agents targeting single mechanisms might be 
particularly useful in clinical settings [11-14]. In the subsequent sections, a brief discussion regarding data covered in Tables 1 and 2 is provided.

\subsection{Treatments Acting on Voltage-Gated Sodium Channels}

The role of Nav in physiological nociception and different pain states has been confirmed in numerous preclinical studies $[37,38,71]$ and several clinical observations $[36,91,106]$, therefore substances blocking Nav receive special attention in pain medicine in humans [113].

Table 1. Receptors, ion channels, enzymes with excitatory mode of action, involved in generation and maintenance of NP, potentially targeted by topically administered treatments. Possible site of action of topical agents, addressing given molecular target. Abbreviations: Nav-voltage-gated sodium channels, TRPV1 - transient receptor potential vanilloid 1, VGCC — voltage-gated calcium channels, NMDAR-N-methyl-D-aspartate receptors, $\alpha 1$-AR — $\alpha 1$ adreno receptors, COX-2—cyclooxygenase-2, NSAID—nonsteroidal anti-inflammatory drug, SNAP-25—synaptosome-associated protein 25.

\begin{tabular}{|c|c|c|c|c|}
\hline \multirow{8}{*}{ EXCITATORY } & $\begin{array}{c}\text { Receptor } \\
\text { Ion Channel } \\
\text { Enzyme }\end{array}$ & $\begin{array}{l}\text { Topical Agent } \\
\text { Utilized in } \\
\text { Clinical Practice }\end{array}$ & $\begin{array}{c}\text { Possible Site of } \\
\text { Action }\end{array}$ & Reference \\
\hline & $\mathrm{Nav}$ & $\begin{array}{c}\text { Lidocaine } \\
\text { Antidepressants: } \\
\text {-Amitriptyline } \\
\text {-Doxepin } \\
\text { Phenytoin } \\
\text { Ambroxol } \\
\text { TV-45070 } \\
\text { Opioids } \\
\text { NSAIDs } \\
\text { Clonidine }\end{array}$ & $\begin{array}{c}\text { Neurons } \\
\text { Keratinocytes }\end{array}$ & $\begin{array}{c}{[36-} \\
38,91,106,114- \\
123]\end{array}$ \\
\hline & TRPV1 & $\begin{array}{l}\text { Capsaicin } \\
\text { NSAIDs }\end{array}$ & $\begin{array}{c}\text { Neurons } \\
\text { Keratinocytes } \\
\text { Immune cells }\end{array}$ & $\begin{array}{c}{[69,70,76,93,94} \\
97,124-128]\end{array}$ \\
\hline & VGCC & $\begin{array}{l}\text { Gabapentin } \\
\text { Lidocaine }\end{array}$ & $\begin{array}{c}\text { Neurons } \\
\text { Keratinocytes }\end{array}$ & $\begin{array}{c}{[39,61,76,91,94,} \\
96,129-133]\end{array}$ \\
\hline & NMDAR & $\begin{array}{c}\text { Ketamine } \\
\text { Antidepressants: } \\
\text {-amitriptyline } \\
\text { NSAID- } \\
\text { Diclofenac }\end{array}$ & $\begin{array}{l}\text { Neurons } \\
\text { Keratinocytes } \\
\text { Immune cells }\end{array}$ & $\begin{array}{c}{[95,134-} \\
136,136,137,137- \\
142]\end{array}$ \\
\hline & $\alpha 1-\mathrm{AR}$ & $\begin{array}{c}\text { Prazosin } \\
\text { Antidepressants }\end{array}$ & $\begin{array}{l}\text { Neurons } \\
\text { Keratinocytes } \\
\text { Immune cells }\end{array}$ & $\begin{array}{c}{[31,33,43-} \\
46,67,73,143- \\
145]\end{array}$ \\
\hline & COX-2 & NSAIDs & $\begin{array}{c}\text { Neurons } \\
\text { Immune cells } \\
\text { Schwann cells }\end{array}$ & {$[75,146,147]$} \\
\hline & SNAP-25 & $\begin{array}{l}\text { Botulinum toxin } \\
\text { A }\end{array}$ & $\begin{array}{c}\text { Neurons } \\
\text { Immune cells } \\
\text { Glial cells }\end{array}$ & [148-151] \\
\hline
\end{tabular}


Table 2. Receptors, ion channels with inhibitory mode of action, involved in modulation of NP, potentially targeted by topically administered treatments. Possible site of action of topical agents, addressing given molecular target. Abbreviations: GABAR-gamma-aminobutyric acid receptors, GABAAR — gamma-aminobutyric acid receptors A, GABABR—gamma-aminobutyric acid receptors $\mathrm{B}, \alpha 2-\mathrm{AR}-\alpha 2$ adreno receptors, $\mathrm{OR}$-opioid receptors, $\mathrm{CB}$ - cannabinoid receptors.

\begin{tabular}{|c|c|c|c|c|}
\hline \multirow{7}{*}{ INHIBITORY } & $\begin{array}{c}\text { Receptor } \\
\text { Ion Channel }\end{array}$ & $\begin{array}{l}\text { Topical Agent } \\
\text { Utilized in } \\
\text { Clinical Practice }\end{array}$ & $\begin{array}{c}\text { Possible Site of } \\
\text { Action }\end{array}$ & Reference \\
\hline & GABAR & $\begin{array}{c}\text { Antidepressants: } \\
\text { Amitriptyline }\end{array}$ & \multirow{3}{*}{$\begin{array}{l}\text { Neurons } \\
\text { Keratinocytes } \\
\text { Immune cells }\end{array}$} & $\begin{array}{c}{[83,84,152,153,} \\
157]\end{array}$ \\
\hline & GABAAR & $\begin{array}{l}\text { Ketamine } \\
\text { Phenytoin }\end{array}$ & & {$[158,159]$} \\
\hline & GABABR & Baclofen & & [154-156] \\
\hline & $\alpha 2-\mathrm{AR}$ & Clonidine & Neurons & [160-164] \\
\hline & OR & Opioids & $\begin{array}{l}\text { Neurons } \\
\text { Keratinocytes } \\
\text { Immune cells }\end{array}$ & $\begin{array}{c}{[79,80,82,165-} \\
170]\end{array}$ \\
\hline & $\mathrm{CB}$ & Cannabinoids & $\begin{array}{l}\text { Neurons } \\
\text { Keratinocytes } \\
\text { Immune cells }\end{array}$ & $\begin{array}{c}{[78,81,98-} \\
100,171-174]\end{array}$ \\
\hline
\end{tabular}

Topically applied lidocaine, phenytoin, antidepressants (amitriptyline, doxepin) and ambroxol are thought to exert their antinociceptive effect in patients with LNP mainly via Nav inhibition [114-121]. In clinical practice, topical treatments acting on Nav provide beneficial analgesic effect; however, $5 \%$ lidocaine patches only have scientific evidence sufficient to position this treatment in clinical recommendations for NP management $[109,110]$.

In clinical studies conducted in patients with PHN specific blocker of Nav1.7 (TV45070) has been assessed as well, but no statistical difference was observed between active treatment and placebo for the change in mean daily pain scores from baseline compared with the last week [122].

Other substances being suggested to exert their antinociceptive effect via Nav blockade in vitro in peripheral nerves include NSAIDs, opioids, $\alpha 2$-AR agonists, and plant-derived compounds, which has been extensively reviewed by Kumamoto [123].

\subsection{Treatments Acting on Transient Receptor Potential Vanilloid 1 Channels}

Some members of the TRP family deserve special attention in pain medicine, as they are expressed in nociceptors, play crucial role in physiological nociception (TRPV1-4, TRPM8, and TRPA1), and are also involved in the generation and maintenance of chronic pain $[69,70,76,93,94,124]$. The available data suggest that, in particular, TRPV1 expressed by C-fibers nociceptors may play an important role in nociception and in pathomechanism of neuropathic and inflammatory pain $[69,70,76,93,94,97,125]$. Moreover, TRPV1 channels are widely distributed in peripheral and central nervous systems, and in other non-neuronal cells involved in peripheral nociception such as keratinocytes and immune cells [125].

Capsaicin is a highly selective agonist of the TRPV1 channels utilized in clinical setting either in low $(<0.1 \%)$ or in high ( $8 \%$ patches) concentration [126]. Clinical evidence supports only $8 \%$ capsaicin patches in patients with LNP $[109,110,127]$, whereas the evidence for the low concentration capsaicin is inconclusive $[109,110]$. Although capsaicin is the potent agonist of TRPV1, its long term analgesic effect relies on the massive intracellular influx of ions $\left(\mathrm{Ca}^{2+}, \mathrm{Cl}^{-}\right)$following activation of TRPV1 and subsequent damage of the cytoskeleton and mitochondria. This leads to the defunctionalisation of hyperexcitable nociceptive receptors, or a temporary destruction of peripheral nerve endings [125]. 
Other drugs acting via TRPV1 include NSAIDs such as diclofenac, ketorolac, xefocam, which, applied topically in rats inhibited pain behaviour, most probably by inhibition of TRPV1 and TRPA1 channels [128].

\subsection{Treatments Acting on Voltage-Gated Calcium Channels}

VGCCs are widely distributed in neuronal and non-neuronal cells. Studies confirmed expression of L-type calcium channel in excitable cells [129] and in epidermal keratinocytes, where they play role in skin barrier homeostasis [96]. In turn the activity of T-type calcium channels is increased in NP states, such as traumatic nerve injury, peripheral diabetic neuropathy or CIPN (chemotherapy-induced peripheral neuropathy) [39,61,76,91,94,130,131]

In clinical settings, VGCC blocker gabapentin administered orally is commonly used and recommended as the first line treatment in patients with NP [109,110]. Single observational studies and case reports report beneficial analgesic effect in patients with LNP states after topical administration of cream containing gabapentin, but the scientific evidence is inconclusive [132].

Other drugs possibly acting via VGCC blockade include lidocaine, however in vitro the VGCC blockade has been observed in lidocaine concentrations 100-fold higher than needed for Nav blockade [133].

\subsection{Treatments Acting on N-Methyl-D-aspartate Receptors}

The role of neuronal NMDAR in generation of peripheral neuroinflammation and central sensitization has been confirmed in several preclinical and clinical studies [134-136]. Moreover, the experimental studies confirmed the expression of functionally active NMDAR in keratinocytes in human normal and inflamed skin, where they play a role in epidermal homeostasis and nociception [95,137].

Ketamine, an anaesthetic drug, is suggested to act topically by blockade of NMDAR and subsequent inhibition of glutamate release $[136,138]$. In clinical trials topical ketamine is more commonly used in combination with other drugs, showing beneficial analgesic effect in patients with different NP syndromes [139], however human studies on topical ketamine as a single agent are inconsistent [140].

Other drugs with possible antinociceptive effect via NMDAR blockade include antidepressants (i.e., amitriptyline) — but this effect has been observed in cultured rat brain neurons only [141] — and diclofenac, providing antinociceptive effect after topical administration in rats [142].

\subsection{Treatments Acting on $\alpha 1$ Adrenergic Receptors}

The role of autonomic system and adrenergic receptors in generation and maintenance of NP has been confirmed $[31,33,43-46,67,73]$. Upregulated $\alpha 1$-AR in peripheral neurons, keratinocytes, and immune cells may be targeted by prazosin, an antagonist of $\alpha 1$-AR [143]. Topically administered prazosin has been studied in one study in healthy volunteers and patients with CRPS to date, showing analgesic effect [144].

Other drugs with possible antinociceptive effect related to $\alpha 1$-AR blockade are antidepressants such as nortriptyline, imipramine, maprotiline, and milnacipran. Their antinociceptive effect via AR blockade has been observed after systemic administration in formalin test only [145]. However, whether amitriptyline acts via $\alpha 1$-AR blockade is unclear.

\subsection{Treatments Acting on Cyclooxygenase 2}

After peripheral nerve injury, PGs may be synthetized not only in invaded immune cells, but in neuronal and glial cells as well. PGs regulates the function of peripheral sensory nerves in paracrine and autocrine manners in several models of NP [75]. Topically administered NSAIDs may interfere with the proinflammatory and pronociceptive effects of PGs by their ability to inhibit the cyclooxygenase COX-2. 
In clinical studies, gel containing $1.5 \%$ diclofenac gave satisfactory pain relief in patients with NP syndromes, however the evidence was medium [146]. Topical NSAIDs are not widely used in patients with NP, rather recommended and commonly used in pain syndromes with predominant inflammatory mechanism [147].

\subsection{Treatments Acting on Synaptosome-Associated Protein 25}

Among the topical analgesics in NP, BTX-A deserves special attention, because when given topically in the periphery, it can directly modulate both central and peripheral sensitization. Recent animal studies proved that topical BTX-A administration is possibly followed by the retrograde transport and transcytosis, which are responsible for pain relief [148-151].

In clinical practice, local injections of BTX-A are recommended as the third-line treatment in patients with LNP, but scientific evidence for its use is weak $[109,110]$.

\subsection{Treatments Acting on Gamma-Aminobutyric Acid Receptors}

GABA is the major inhibitory neurotransmitter in the adult mammalian central nervous system and exerts inhibitory action via specific receptors named GABAAR and GABABR. GABAAR are ion channels located in postsynaptic membranes, whereas GABABR are GPCR located both in pre- and postsynaptic membranes [152]. Moreover, GABAR are expressed in immune and skin cells, where they are involved in skin barrier homeostasis and skin inflammatory diseases $[83,84,153]$. In preclinical studies, the role of peripheral GABABR in nociception has been confirmed in animal model of allodynia [154].

In clinical settings, baclofen, a specific agonist of GABABR, is utilized topically in patients with NP syndromes in a mono- or add-on therapy, but the evidence of its efficacy is inconclusive $[155,156]$.

Other drugs possibly acting by GABA receptors include:

- $\quad$ antidepressants (amitriptylline, fluoxetine), but their antinociceptive effect has been observed after intraperitoneal administration in rats [157];

- ketamine - the agonist to GABAAR, which has been confirmed in an anesthetic model in mice [158];

- $\quad$ phenytoin, which potentiated GABA-induced currents in cultured rat cortical neurons through modulation of the GABAAR [159].

\subsection{Treatments Acting on $\alpha 2$ Adreno Receptors}

The $\alpha 2$-AR are inhibitory G-protein coupled receptors involved in nociception and expressed in peripheral and central nervous system [160-162]. Activation of these receptors induces antinociception in animal models of NP [160] and reduced production of TNF $\alpha$, IL-6, IL-8 in in vitro studies [163].

Clonidine, an agonist for $\alpha 2$-AR receptors, is an extremely potent antinociceptive agent when given systemically. However, topical clonidine exerts an analgesic effect in patients with LNP with medium level of evidence [164].

\subsection{Treatments Acting on Opioid Receptors}

The peripheral inflammation increases de novo synthesis of OR in DRG and their density in the peripheral nerve endings, whereas nerve injury decreases MOR ( $\mu$ opioid receptor) expression in peripheral nerves [165]. However, peripheral nerve injury via cytokines, especially chemokines and other factors recruits immune cells to the site of injury. Moreover, recruited immune cells release endogenous opioids and express all types of OR $[79,166]$. Besides, OR are expressed as well by keratinocytes, which can produce $\beta$-endorphins [167]. Taken together, following peripheral injury, OR expressed by neuronal and non-neuronal cells and their endogenous agonists form a complex system, modulating nociception at the peripheral level [82]. Therefore, there is a rationale for topical use of opioids, without involvement of central mechanism of action, which has been confirmed in NP models $[80,168]$. 
In clinical practice, loperamide has been used in patients with NP, however evidence is limited to single case report only [169]. To date, morphine in topical formulation showed beneficial effect in patients with painful mucosal or skin lesions due to cancer [170], but the data on topical morphine in NP is lacking.

\subsection{Treatments Acting on Cannabinoid Receptors}

Numerous studies indicate a modulatory effect of the endocannabinoid system in NP [171]. In the periphery, CB1 receptors are expressed on nociceptive nerve endings and the DRG, whereas CB2 receptors are located in immune cells and keratinocytes $[78,172]$. Either CB1 or CB2 receptors may be targeted by cannabinoids administered topically, evoking analgesic effect in both inflammatory and neuropathic pain [78,81,98-100,172].

Clinical observations indicate that topical administration of CBD (cannabidiol), mixed with other well-known anti-inflammatory phytoderived products, exert analgesic and anti-inflammatory effect, but evidence is weak and comes from single studies on inflammatory pain only [173]. In patients with vulvodynia, beneficial analgesic effect of topically administered 1\% PAE (palmitoylethanolamide), an endocannabinoid anti-inflammatory compound, with $5 \%$ baclofen has been observed [174]. The clinical observations support the topical application of cannabinoids, but data and evidence on their efficacy in LNP syndromes are lacking.

\section{Conclusions}

The progress made in identification of peripheral mechanisms of NP, peripheral neuronal and non-neuronal cells interplay, and the role of peripheral sensitization in modulation of central hypersensitivity has given a stronger rational basis for topical treatments in clinical practice and experimental research on novel agents. It is accepted that primary sensory afferent neurons, immune cells, and keratinocytes express numerous ion channels and receptors, release signaling molecules in a response of injury, and can be activated or suppressed by a wide range of pro- or antinociceptive mediators, respectively. Modulation of their complex interactions in the periphery represents a strategy for the development of new topical analgesics and their utilization in clinical settings.

Author Contributions: Conceptualization, M.K.-K., R.Z., J.M., J.W., J.D., A.P.-M.; validation, M.K.-K., R.Z., J.M., J.W., J.D., A.P.-M.; writing—original draft preparation, M.K.-K., R.Z., J.M., J.W., J.D., A.P.-M.; writing-review and editing, M.K.-K., R.Z., J.M., J.W., J.D., A.P.-M.; visualization, M.K.-K.; supervision, J.W., J.D.; project administration, A.P.-M., J.M., J.W.; funding acquisition, M.K.-K., A.P.-M., J.W. All authors have read and agreed to the published version of the manuscript.

Funding: This work was supported by the by statutory funds of Jagiellonian University Medical College, Krakow, Poland, and by statutory funds of the Maj Institute of Pharmacology, Polish Academy of Sciences, Department of Pain Pharmacology, Krakow, Poland.

Conflicts of Interest: The authors declare no conflict of interest.

\section{References}

1. Jensen, T.S.; Baron, R.; Haanpää, M.; Kalso, E.; Loeser, J.D.; Rice, A.S.; Treede, R.D. A new definition of neuropathic pain. Pain 2011, 152, 2204-2205. [CrossRef] [PubMed]

2. Morlion, B.; Coluzzi, F.; Aldington, D.; Kocot-Kepska, M.; Pergolizzi, J.; Mangas, A.C.; Ahlbeck, K.; Kalso, E. Pain chronification: What should a non-pain medicine specialist know? Curr. Med. Res. Opin. 2018, 34, 1169-1178. [CrossRef] [PubMed]

3. Cairns, B.E.; Arendt-Nielsen, L.; Sacerdote, P. Perspectives in Pain Research 2014: Neuroinflammation and glial cell activation: The cause of transition from acute to chronic pain? Scand. J. Pain 2015, 6, 3-6. [CrossRef] [PubMed]

4. Colloca, L.; Ludman, T.; Bouhassira, D.; Baron, R.; Dickenson, A.H.; Yarnitsky, D.; Freeman, R.; Truini, A.; Attal, N.; Finnerup, N.B.; et al. Neuropathic pain. Nat. Rev. Dis. Primers 2017, 3, 17002. [CrossRef] [PubMed]

5. Malcangio, M. Role of the immune system in neuropathic pain. Scand. J. Pain 2019, 20, 33-37. [CrossRef] [PubMed]

6. Casale, R.; Mattia, C. Building a diagnostic algorithm on localized neuropathic pain (LNP) and targeted topical treatment: Focus on 5\% lidocaine-medicated plaster. Ther. Clin. Risk Manag. 2014, 10, 259-268. [CrossRef]

7. Mick, G.; Baron, R.; Brix Finnerup, N.; Hans, G.; Kern, K.U.; Brett, B.; Dworkin, R.H. What is localized neuropathic pain? A first proposal to characterize and define a widely used term. Pain Manag. 2012, 2, 71-77. [CrossRef] 
8. Raja, S.N.; Ringkamp, M.; Guan, Y.; Campbell, J.N.; John, J. Bonica Award Lecture: Peripheral neuronal hyperexcitability: The "low-hanging" target for safe therapeutic strategies in neuropathic pain. Pain 2020, 161 (Suppl. 1), S14-S26. [CrossRef]

9. Müller-Schwefe, G.; Morlion, B.; Ahlbeck, K.; Alon, E.; Coaccioli, S.; Coluzzi, F.; Huygen, F.; Jaksch, W.; Kalso, E.; Kocot-Kępska, M.; et al. Treatment for chronic low back pain: The focus should change to multimodal management that reflects the underlying pain mechanisms. Curr. Med. Res. Opin. 2017, 33, 1199-1210. [CrossRef]

10. Casale, R.; Symeonidou, Z.; Bartolo, M. Topical Treatments for Localized Neuropathic Pain. Curr. Pain Headache Rep. 2017, 21, 15. [CrossRef]

11. Hesselink, J.M.; Kopsky, D.J.; Bhaskar, A.K. Skin matters! The role of keratinocytes in nociception: A rational argument for the development of topical analgesics. J. Pain Res. 2016, 16, 1-8. [CrossRef] [PubMed]

12. Shipton, E.A. Skin matters: Identifying pain mechanisms and predicting treatment outcomes. Neurol. Res. Int. 2013, 2013, 329364. [CrossRef] [PubMed]

13. Sawynok, J. Topical and peripherally acting analgesics. Pharmacol. Rev. 2003, 55, 1-20. [CrossRef] [PubMed]

14. De Leon-Casasola, O.A. Multimodal approaches to the management of neuropathic pain: The role of topical analgesia. J. Pain Symptom Manag. 2007, 33, 356-364. [CrossRef] [PubMed]

15. Von Hehn, C.A.; Baron, R.; Woolf, C.J. Deconstructing the neuropathic pain phenotype to reveal neural mechanisms. Neuron 2012, 73, 638-652. [CrossRef]

16. Baron, R.; Binder, A.; Wasner, G. Neuropathic pain: Diagnosis, pathophysiological mechanisms, and treatment. Lancet Neurol. 2010, 9, 807-819. [CrossRef]

17. Meacham, K.; Shepherd, A.; Mohapatra, D.P.; Haroutounian, S. Neuropathic Pain: Central vs. Peripheral Mechanisms. Curr. Pain Headache Rep. 2017, 21, 28. [CrossRef]

18. Bouhassira, D.; Attal, N.; Alchaar, H.; Boureau, F.; Brochet, B.; Bruxelle, J.; Cunin, G.; Fermanian, J.; Ginies, P.; Grun-Overdyking, A.; et al. Comparison of pain syndromes associated with nervous or somatic lesions and development of a new neuropathic pain diagnostic questionnaire (DN4). Pain 2005, 114, 29-36. [CrossRef]

19. Haroutounian, S.; Nikolajsen, L.; Bendtsen, T.F.; Finnerup, N.B.; Kristensen, A.D.; Hasselstrøm, J.B.; Jensen, T.S. Primary afferent input critical for maintaining spontaneous pain in peripheral neuropathy. Pain 2014, 155, 1272-1279. [CrossRef]

20. Colleoni, M.; Sacerdote, P. Murine models of human neuropathic pain. Biochim. Biophys. Acta. 2010, 1802, 924-933. [CrossRef]

21. Sousa, A.M.; Lages, G.V.; Pereira, C.L.; Slullitel, A. Experimental models for the study of neuropathic pain. Modelos experimentais para o estudo da dor neuropática. Rev. Dor. São Paulo 2016, 17 (Suppl. 1), S27-S30.

22. Kuner, R.; Flor, H. Structural plasticity and reorganisation in chronic pain. Nat. Rev. Neurosci. 2016, 18, 20-30. [CrossRef] [PubMed]

23. Wodarski, R.; Bagdas, D.; Paris, J.J.; Pheby, T.; Toma, W.; Xu, R.; Damaj, M.I.; Knapp, P.E.; Rice, A.S.C.; Hauser, K.F. Reduced intraepidermal nerve fibre density, glial activation, and sensory changes in HIV type-1 Tat-expressing female mice: Involvement of Tat during early stages of HIV-associated painful sensory neuropathy. Pain Rep. 2018, 14, e654. [CrossRef] [PubMed]

24. Wozniak, K.M.; Vornov, J.J.; Wu, Y.; Liu, Y.; Carozzi, V.A.; Rodriguez-Menendez, V.; Ballarini, E.; Alberti, P.; Pozzi, E.; Semperboni, S.; et al. Peripheral Neuropathy Induced by Microtubule-Targeted Chemotherapies: Insights into Acute Injury and Long-term Recovery. Cancer Res. 2018, 78, 817-829. [CrossRef] [PubMed]

25. Davies, A.J.; Rinaldi, S.; Costigan, M.; Oh, S.B. Cytotoxic Immunity in Peripheral Nerve Injury and Pain. Front. Neurosci. 2020, 14, 142. [CrossRef]

26. Ratte, S.; Prescott, S.A. Afferent hyperexcitability in neuropathic pain and the inconvenient truth about its degeneracy. Curr. Opin. Neurobiol. 2016, 36, 31-37. [CrossRef]

27. Dubový, P. Wallerian degeneration and peripheral nerve conditions for both axonal regeneration and neuropathic pain induction. Ann. Anat. Anat. Anz. 2011, 193, 267-275. [CrossRef]

28. Gaudet, A.D.; Popovich, P.G.; Ramer, M.S. Wallerian degeneration: Gaining perspective on inflammatory events after peripheral nerve injury. J. Neuroinflamm. 2011, 8, 110. [CrossRef]

29. Ochoa, J.L.; Campero, M.; Serra, J.; Bostock, H. Hyperexcitable polymodal and insensitive nociceptors in painful human neuropathy. Muscle Nerve 2005, 32, 459-472. [CrossRef]

30. Si-Qi, W.; Zhuo-Ying, T.; Yang, X.; Dong-Yuan, C. Peripheral Sensitization. In Peripheral Nerve Disorders and Treatment; Turker, H., Benavides, L.G., Gallardo, G.R., del Villar, M.M., Eds.; IntechOpen: London, UK, 4 December 2019; Available online: https: //www.intechopen.com/books/peripheral-nerve-disorders-and-treatment/peripheral-sensitization (accessed on 2 December 2020). [CrossRef]

31. Liu, X.; Chung, K.; Chung, J.M. Ectopic discharges and adrenergic sensitivity of sensory neurons after spinal nerve injury. Brain Res. 1999, 849, 244-247. [CrossRef]

32. Truini, A. A review of neuropathic pain: From diagnostic tests to mechanisms. Pain Ther. 2017, 6, 5-9. [CrossRef] [PubMed]

33. Ali, Z.; Ringkamp, M.; Hartke, T.V.; Chien, H.F.; Flavahan, N.A.; Campbell, J.N.; Meyer, R.A. Uninjured C-fiber nociceptors develop spontaneous activity and alpha-adrenergic sensitivity following L6 spinal nerve ligation in monkey. J. Neurophysiol. 1999, 81, 455-466. [CrossRef] [PubMed]

34. North, R.Y.; Lazaro, T.T.; Dougherty, P.M. Ectopic spontaneous afferent activity and neuropathic pain. Neurosurgery 2018, 65, 49-54. [CrossRef] [PubMed] 
35. Liu, F.; Wuni, G.Y.; Bahuva, R. Pacemaking Activity in the Peripheral Nervous System: Physiology and Roles of Hyperpolarization Activated and Cyclic Nucleotide-Gated Channels in Neuropathic Pain. Cureus 2020, 12, e11111. [CrossRef]

36. Dib-Hajj, S.D.; Rush, A.M.; Cummins, T.R.; Hisama, F.M.; Novella, S.; Tyrrell, L.; Marshall, L.; Waxman, S.G. Gain-of-function mutation in Nav1.7 in familial erythromelalgia induces bursting of sensory neurons. Brain 2005, 128, 1847-1854. [CrossRef]

37. Novakovic, S.D.; Tzoumaka, E.; McGivern, J.G.; Haraguchi, M.; Sangameswaran, L.; Gogas, K.R.; Eglen, R.M.; Hunter, J.C. Distribution of the tetrodotoxin-resistant sodium channel PN3 in rat sensory neurons in normal and neuropathic conditions. J. Neurosci. 1998, 15, 2174-2187. [CrossRef]

38. Dib-Hajj, S.D.; Fjell, J.; Cummins, T.R.; Zheng, Z.; Fried, K.; LaMotte, R.; Black, J.A.; Waxman, S.G. Plasticity of sodium channel expression in DRG neurons in the chronic constriction injury model of neuropathic pain. Pain 1999, 83, 591-600. [CrossRef]

39. Li, Y.; Tatsui, C.E.; Rhines, L.D.; North, R.Y.; Harrison, D.S.; Cassidy, R.M.; Johansson, C.A.; Kosturakis, A.K.; Edwards, D.D.; Zhang, H.; et al. Dorsal root ganglion neurons become hyperexcitable and increase expression of voltage-gated T-type calcium channels (Cav3.2) in paclitaxel-induced peripheral neuropathy. Pain 2017, 158, 417-429. [CrossRef]

40. Li, Y.; Zhang, H.; Zhang, H.; Kosturakis, A.K.; Jawad, A.B.; Dougherty, P.M. Toll-like receptor 4 signaling contributes to Paclitaxel-induced peripheral neuropathy. J. Pain 2014, 15, 712-725. [CrossRef]

41. Woolf, C.J.; Shortland, P.; Coggeshall, R.E. Peripheral nerve injury triggers central sprouting of myelinated afferents. Nature 1992, 355, 75-78. [CrossRef]

42. Zhu, Y.F.; Kwiecien, J.M.; Dabrowski, W.; Ungard, R.; Zhu, K.L.; Huizinga, J.D.; Henry, J.L.; Singh, G. Cancer pain and neuropathic pain are associated with A $\beta$ sensory neuronal plasticity in dorsal root ganglia and abnormal sprouting in lumbar spinal cord. Mol. Pain 2018, 14, 1744806918810099. [CrossRef] [PubMed]

43. Drummond, P.D. Neuronal changes resulting in up-regulation of alpha-1 adrenoceptors after peripheral nerve injury. Neural. Regen. Res. 2014, 15, 1337-1340. [CrossRef] [PubMed]

44. Nascimento, F.P.; Magnussen, C.; Yousefpour, N.; Ribeiro-da-Silva, A. Sympathetic fibre sprouting in the skin contributes to pain-related behaviour in spared nerve injury and cuff models of neuropathic pain. Mol. Pain 2015, 11, 59. [CrossRef] [PubMed]

45. Yen, L.D.; Bennett, G.J.; Ribeiro-da-Silva, A. Sympathetic sprouting and changes in nociceptive sensory innervation in the glabrous skin of the rat hind paw following partial peripheral nerve injury. J. Comp. Neurol. 2006, 495, 679-690. [CrossRef] [PubMed]

46. Ramer, M.S.; Bisby, M.A. Adrenergic innervation of rat sensory ganglia following proximal or distal painful sciatic neuropathy: Distinct mechanisms revealed by anti-NGF treatment. Eur. J. Neurosci. 1999, 11, 837-846. [CrossRef]

47. Hsieh, M.T.; Donaldson, L.F.; Lumb, B.M. Differential contributions of A- and C-nociceptors to primary and secondary inflammatory hypersensitivity in the rat. Pain 2015, 156, 1074-1083. [CrossRef]

48. Hulse, R.P. Identification of mechano-sensitive $C$ fibre sensitization and contribution to nerve injury-induced mechanical hyperalgesia. Eur. J. Pain 2016, 20, 615-625. [CrossRef]

49. Forstenpointner, J.; Naleschinski, D.; Wasner, G.; Hüllemann, P.; Binder, A.; Baron, R. Sensitized vasoactive C-nociceptors: Key fibers in peripheral neuropathic pain. PAIN Rep. 2019, 4, e709. [CrossRef]

50. Devor, M. Ectopic discharge in Abeta afferents as a source of neuropathic pain. Exp. Brain Res. 2009, 196, 115-128. [CrossRef]

51. Zhu, Y.F.; Wu, Q.; Henry, J.L. Changes in functional properties of A-type but not C-type sensory neurons in vivo in a rat model of peripheral neuropathy. J. Pain Res. 2012, 5, 175-192. [CrossRef]

52. Djouhri, L.; Zeidan, A.; Abd El-Aleem, S.A.; Smith, T. Cutaneous A $\beta$-Non-nociceptive, but Not C-Nociceptive, Dorsal Root Ganglion Neurons Exhibit Spontaneous Activity in the Streptozotocin Rat Model of Painful Diabetic Neuropathy in vivo. Front. Neurosci. 2020, 25, 530. [CrossRef] [PubMed]

53. Zhu, Y.F.; Henry, J.L. Excitability of A $\beta$ sensory neurons is altered in an animal model of peripheral neuropathy. BMC Neurosci. 2012, 30, 15. [CrossRef] [PubMed]

54. Djouhri, L. L5 spinal nerve axotomy induces sensitization of cutaneous L4 A $\beta$-nociceptive dorsal root ganglion neurons in the rat in vivo. Neurosci. Lett. 2016, 15, 72-77. [CrossRef] [PubMed]

55. Ji, R.R.; Berta, T.; Nedergaard, M. Glia and pain: Is chronic pain a gliopathy? Pain 2013, 154 (Suppl. 1), S10-S28. [CrossRef] [PubMed]

56. Mika, J.; Zychowska, M.; Popiolek-Barczyk, K.; Rojewska, E.; Przewlocka, B. Importance of glial activation in neuropathic pain. Eur. J. Pharmacol. 2013, 15, 106-119. [CrossRef]

57. Kidd, G.J.; Ohno, N.; Trapp, B.D. Biology of Schwann cells. Handb. Clin. Neurol. 2013, 115, 55-79. [CrossRef]

58. Yajima, Y.; Narita, M.; Usui, A.; Kaneko, C.; Miyatake, M.; Narita, M.; Yamaguchi, T.; Tamaki, H.; Wachi, H.; Seyama, Y.; et al. Direct evidence for the involvement of brain-derived neurotrophic factor in the development of a neuropathic pain-like state in mice. J. Neurochem. 2005, 93, 584-594. [CrossRef]

59. Wei, Z.; Fei, Y.; Su, W.; Chen, G. Emerging Role of Schwann Cells in Neuropathic Pain: Receptors, Glial Mediators and Myelination. Front. Cell Neurosci. 2019, 27, 116. [CrossRef]

60. Lee, H.; Baek, J.; Min, H.; Cho, I.H.; Yu, S.W.; Lee, S.J. Toll-Like Receptor 3 Contributes to Wallerian Degeneration after Peripheral Nerve Injury. Neuroimmunomodulation 2016, 23, 209-216. [CrossRef]

61. Park, K.M.; Bowers, W.J. Tumor necrosis factor-alpha mediated signaling in neuronal homeostasis and dysfunction. Cell Signal. 2010, 22, 977-983. [CrossRef] 
62. Ji, R.R.; Chamessian, A.; Zhang, Y.Q. Pain regulation by non-neuronal cells and inflammation. Science 2016, $354,572-577$. [CrossRef] [PubMed]

63. Ristoiu, V. Contribution of macrophages to peripheral neuropathic pain pathogenesis. Life Sci. 2013, 93, 870-881. [CrossRef] [PubMed]

64. Liu, P.; Peng, J.; Han, G.H.; Ding, X.; Wei, S.; Gao, G.; Huang, K.; Chang, F.; Wang, Y. Role of macrophages in peripheral nerve injury and repair. Neural. Regen. Res. 2019, 14, 1335-1342. [CrossRef] [PubMed]

65. Sica, A.; Mantovani, A. Macrophage plasticity and polarization: In vivo veritas. J. Clin. Investig. 2012, 122, 787-795. [CrossRef] [PubMed]

66. Christianson, C.A.; Dumlao, D.S.; Stokes, J.A.; Dennis, E.A.; Svensson, C.I.; Corr, M.; Yaksh, T.L. Spinal TLR4 mediates the transition to a persistent mechanical hypersensitivity after the resolution of inflammation in serum-transferred arthritis. Pain 2011, 152, 2881-2891. [CrossRef] [PubMed]

67. Grisanti, L.A.; Woster, A.P.; Dahlman, J.; Sauter, E.R.; Combs, C.K.; Porter, J.E. $\alpha 1$-adrenergic receptors positively regulate Toll-like receptor cytokine production from human monocytes and macrophages. J. Pharmacol. Exp. Ther. 2011, 338, 648-657. [CrossRef] [PubMed]

68. Ren, K.; Dubner, R. Interactions between the immune and nervous systems in pain. Nat. Med. 2010, 16, 1267-1276. [CrossRef]

69. Zhang, N.; Inan, S.; Cowan, A.; Sun, R.; Wang, J.M.; Rogers, T.J.; Caterina, M.; Oppenheim, J.J. A proinflammatory chemokine, CCL3, sensitizes the heat- and capsaicin-gated ion channel TRPV1. Proc. Natl. Acad. Sci. USA 2005, 102, 4536-4541. [CrossRef]

70. Obreja, O.; Rathee, P.K.; Lips, K.S.; Distler, C.; Kress, M. IL-1 potentiates heat-activated currents in rat sensory neurons: Involvement of IL-1RI, tyrosine kinase, and protein kinase C. FASEB J. 2002, 16, 1497-1503. [CrossRef]

71. Jin, X.; Gereau, R.W., 4th. Acute p38-mediated modulation of tetrodotoxin-resistant sodium channels in mouse sensory neurons by tumor necrosis factor-alpha. J. Neurosci. 2006, 4, 246-255. [CrossRef]

72. Schaible, H.G. Nociceptive neurons detect cytokines in arthritis. Arthritis Res. Ther. 2014, 16, 470. [CrossRef] [PubMed]

73. Drummond, P.D.; Dawson, L.F.; Finch, P.M.; Drummond, E.S.; Wood, F.M.; Fear, M.W. Up-regulation of cutaneous alpha1adrenoceptors after a burn. Burns 2015, 41, 1227-1234. [CrossRef] [PubMed]

74. Dawson, L.F.; Phillips, J.K.; Finch, P.M.; Inglis, J.J.; Drummond, P.D. Expression of alpha1-adrenoceptors on peripheral nociceptive neurons. Neuroscience 2011, 175, 300314. [CrossRef] [PubMed]

75. Ma, W.; Chabot, J.G.; Vercauteren, F.; Quirion, R. Injured nerve-derived COX2/PGE2 contributes to the maintenance of neuropathic pain in aged rats. Neurobiol. Aging. 2010, 31, 1227-1237. [CrossRef] [PubMed]

76. Jang, Y.; Kim, M.; Hwang, S.W. Molecular mechanisms underlying the actions of arachidonic acid-derived prostaglandins on peripheral nociception. J. Neuroinflamm. 2020, 17, 30. [CrossRef]

77. Thacker, M.A.; Clark, A.K.; Marchand, F.; McMahon, S.B. Pathophysiology of peripheral neuropathic pain: Immune cells and molecules. Anesth. Analg. 2007, 105, 838-847. [CrossRef] [PubMed]

78. Turcotte, C.; Blanchet, M.R.; Laviolette, M.; Flamand, N. The CB2 receptor and its role as a regulator of inflammation. Cell Mol. Life Sci. 2016, 73, 4449-4470. [CrossRef]

79. Eisenstein, T.K. The Role of Opioid Receptors in Immune System Function. Front. Immunol. 2019, 10, 2904. [CrossRef]

80. Smith, M.T.; Wyse, B.D.; Edwards, S.R.; El-Tamimy, M.; Gaetano, G.; Gavin, P. Topical application of a novel oxycodone gel formulation (tocopheryl phosphate mixture) in a rat model of peripheral inflammatory pain produces localized pain relief without significant systemic exposure. J. Pharm. Sci. 2015, 104, 2388-2396. [CrossRef]

81. D'Amico, R.; Impellizzeri, D.; Cuzzocrea, S.; Di Paola, R. ALIAmides Update: Palmitoylethanolamide and Its Formulations on Management of Peripheral Neuropathic Pain. Int. J. Mol. Sci. 2020, 27, 5330. [CrossRef]

82. Sehgal, N.; Smith, H.S.; Manchikanti, L. Peripherally acting opioids and clinical implications for pain control. Pain Phys. 2011, 14, 249-258.

83. Nigam, R.; El-Nour, H.; Amatya, B.; Nordlind, K. GABA and GABA(A) receptor expression on immune cells in psoriasis: A pathophysiological role. Arch. Dermatol. Res. 2010, 302, 507-515. [CrossRef] [PubMed]

84. Cevikbas, F.; Braz, J.M.; Wang, X.; Solorzano, C.; Sulk, M.; Buhl, T.; Steinhoff, M.; Basbaum, A.I. Synergistic antipruritic effects of gamma aminobutyric acid A and B agonists in a mouse model of atopic dermatitis. J. Allergy Clin. Immunol. 2017, 140, 454-464.e2. [CrossRef] [PubMed]

85. Misery, L. Le système neuro-immuno-cutané (SNIC) [Neuro-immuno-cutaneous system (NICS)]. Pathol. Biol. (Paris) 1996, 44, 867-874. [PubMed]

86. Vidal Yucha, S.E.; Tamamoto, K.A.; Kaplan, D.L. The importance of the neuro-immuno-cutaneous system on human skin equivalent design. Cell Prolif. 2019, 52, e12677. [CrossRef] [PubMed]

87. Pang, Z.; Sakamoto, T.; Tiwari, V. Selective keratinocyte stimulation is sufficient to evoke nociception in mice. Pain 2015, 156, 656-665. [CrossRef] [PubMed]

88. Radtke, C.; Vogt, P.M.; Devor, M.; Kocsis, J.D. Keratinocytes acting on injured afferents induce extreme neuronal hyperexcitability and chronic pain. Pain 2010, 148, 94-102. [CrossRef]

89. Hou, Q.; Barr, T.; Gee, L.; Vickers, J.; Wymer, J.; Borsani, E.; Rodella, L.; Getsios, S.; Burdo, T.; Eisenberg, E.; et al. Keratinocyte expression of calcitonin gene-related peptide $\beta$ : Implications for neuropathic and inflammatory pain mechanisms. Pain 2011, 152, 2036-2051. [CrossRef] 
90. Pan, B.; Schröder, W.; Jostock, R.; Schwartz, M.; Rosson, G.; Polydefkis, M. Nociceptin/orphanin FQ opioid peptide-receptor expression in pachyonychia congenita. J. Peripher. Nerv. Syst. 2018, 23, 241-248. [CrossRef]

91. Zhao, P.; Barr, T.P.; Hou, Q.; Dib-Hajj, S.D.; Black, J.A.; Albrecht, P.J.; Petersen, K.; Eisenberg, E.; Wymer, J.P.; Rice, F.L.; et al. Voltage-gated sodium channel expression in rat and human epidermal keratinocytes: Evidence for a role in pain. Pain 2008, 30, 90-105. [CrossRef]

92. Dussor, G.; Koerber, H.R.; Oaklander, A.L.; Rice, F.L.; Molliver, D.C. Nucleotide signaling and cutaneous mechanisms of pain transduction. Brain Res. Rev. 2009, 60, 2435. [CrossRef]

93. Southall, M.D.; Li, T.; Gharibova, L.S.; Pei, Y.; Nicol, G.D.; Travers, J.B. Activation of epidermal vanilloid receptor-1 induces release of proinflammatory mediators in human keratinocytes. J. Pharmacol. Exp. Ther. 2003, 304, 217-222. [CrossRef] [PubMed]

94. Sloniecka, M.; Le Roux, S.; Boman, P.; Bystrom, B.; Zhou, Q.; Danielson, P. Expression profiles of neuropeptides, neurotransmitters, and their receptors in human keratocytes in vitro and in situ. PLoS ONE 2015, 10, e0134157. [CrossRef] [PubMed]

95. Xu, X.; Tao, X.; Huang, P.; Lin, F.; Liu, Q.; Xu, L.; Xu, J.; Huang, Y. N-methyl-d-aspartate receptor subunit 2B on keratinocyte mediates peripheral and central sensitization in chronic post-ischemic pain in male rats. Brain Behav. Immun. 2020, 87, 579-590 [CrossRef] [PubMed]

96. Denda, M.; Fujiwara, S.; Hibino, T. Expression of voltage-gated calcium channel subunit alpha1C in epidermal keratinocytes and effects of agonist and antagonists of the channel on skin barrier homeostasis. Exp. Dermatol. 2006, 15, 455-460. [CrossRef] [PubMed]

97. Wilder-Smith, E.P.; Ong, W.Y.; Guo, Y.; Chow, A.W. Epidermal transient receptor potential vanilloid 1 in idiopathic small nerve fibre disease, diabetic neuropathy, and healthy human subjects. Histopathology 2007, 51, 674-680. [CrossRef]

98. Gao, F.; Zhang, L.H.; Su, T.F.; Li, L.; Zhou, R.; Peng, M.; Wu, C.H.; Yuan, X.C.; Sun, N.; Meng, X.F.; et al. Signaling Mechanism of Cannabinoid Receptor-2 Activation-Induced $\beta$-Endorphin Release. Mol. Neurobiol. 2016, 53, 3616-3625. [CrossRef]

99. Katsuyama, S.; Mizoguchi, H.; Kuwahata, H.; Komatsu, T.; Nagaoka, K.; Nakamura, H.; Bagetta, G.; Sakurada, T.; Sakurada, S. Involvement of peripheral cannabinoid and opioid receptors in $\beta$-caryophyllene-induced antinociception. Eur. J. Pain 2013, 17, 664-675. [CrossRef]

100. Ibrahim, M.M.; Porreca, F.; Lai, J.; Albrecht, P.J.; Rice, F.L.; Khodorova, A.; Davar, G.; Makriyannis, A.; Vanderah, T.W.; Mata, H.P.; et al. CB2 cannabinoid receptor activation produces antinociception by stimulating peripheral release of endogenous opioids. Proc. Natl. Acad. Sci. USA 2005, 22, 3093-3098. [CrossRef]

101. Irving, G. The role of the skin in peripheral neuropathic pain. Eur. J. Pain Suppl. 2010, 4, 157-160. [CrossRef]

102. Huang, L.Y.; Gu, Y.; Chen, Y. Communication between neuronal somata and satellite glial cells in sensory ganglia. Glia 2013, 61, 1571-1581. [CrossRef] [PubMed]

103. Inoue, K.; Tsuda, M. Microglia in neuropathic pain: Cellular and molecular mechanisms and therapeutic potential. Nat. Rev. Neurosci. 2018, 19, 138-152. [CrossRef] [PubMed]

104. Latremoliere, A.; Woolf, C.J. Central sensitization: A generator of pain hypersensitivity by central neural plasticity. J. Pain 2009, 10, 895-926. [CrossRef] [PubMed]

105. Gracely, R.H.; Lynch, S.A.; Bennett, G.J. Painful neuropathy: Altered central processing maintained dynamically by peripheral input. PAIN 1992, 51, 175-194. [CrossRef]

106. Bennett, D.L.; Woods, C.G. Painful and painless channelopathies. Lancet Neurol. 2014, 13, 587-599. [CrossRef]

107. Drummond, P.D.; Morellini, N.; Finch, P.M.; Birklein, F.; Knudsen, L.F. Complex regional pain syndrome: Intradermal injection of phenylephrine evokes pain and hyperalgesia in a subgroup of patients with upregulated alpha1-adrenoceptors on dermal nerves. PAIN 2018, 159, 2296-2305. [CrossRef] [PubMed]

108. Balkarli, A.; Sengül, C.; Tepeli, E.; Balkarli, H.; Cobankara, V. Synaptosomal-associated protein 25 (Snap-25) gene polymorphism frequency in fibromyalgia syndrome and relationship with clinical symptoms. BMC Musculoskelet. Disord. 2014, $15,191$. [CrossRef] [PubMed]

109. Finnerup, N.B.; Attal, N.; Haroutounian, S.; McNicol, E.; Baron, R.; Dworkin, R.H.; Gilron, I.; Haanpää, M.; Hansson, P.; Jensen, T.S.; et al. Pharmacotherapy for neuropathic pain in adults: A systematic review and meta-analysis. Lancet Neurol. 2015, 14, 162-173. [CrossRef]

110. Moisset, X.; Bouhassira, D.; Avez Couturier, J.; Alchaar, H.; Conradi, S.; Delmotte, M.H.; Lanteri-Minet, M.; Lefaucheur, J.P.; Mick, G.; Piano, V.; et al. Pharmacological and non-pharmacological treatments for neuropathic pain: Systematic review and French recommendations. Rev. Neurol. (Paris) 2020, 176, 325-352. [CrossRef]

111. Fialho, M.; Brum, E.; Pegoraro, N.S.; Couto, A.; Trevisan, G.; Cruz, L.; Oliveira, S.M. Topical transient receptor potential ankyrin 1 antagonist treatment attenuates nociception and inflammation in an ultraviolet B radiation-induced burn model in mice. $J$. Dermatol. Sci. 2020, 97, 135-142. [CrossRef]

112. Ann, J.; Kim, H.S.; Thorat, S.A.; Kim, H.; Ha, H.J.; Choi, K.; Kim, Y.H.; Kim, M.; Hwang, S.W.; Pearce, L.V.; et al. Discovery of Nonpungent Transient Receptor Potential Vanilloid 1 (TRPV1) Agonist as Strong Topical Analgesic. J. Med. Chem. 2020, 63, 418-424. [CrossRef] [PubMed]

113. Cardoso, F.C.; Lewis, R.J. Sodium channels and pain: From toxins to therapies. Br. J. Pharmacol. 2018, 175, 2138-2157. [CrossRef] [PubMed]

114. Kodaira, M.; Inui, K.; Kakigi, R. Evaluation of nociceptive A $\delta$ - and C-fiber dysfunction with lidocaine using intraepidermal electrical stimulation. Clin. Neurophysiol. 2014, 125, 1870-1877. [CrossRef] [PubMed] 
115. Thorn, C.F.; Whirl-Carrillo, M.; Leeder, J.S.; Klein, T.E.; Altman, R.B. PharmGKB summary: Phenytoin pathway. Pharm. Genom. 2012, 22, 466-470. [CrossRef]

116. Kopsky, D.J.; Vrancken, A.F.J.E.; Keppel Hesselink, J.M.; van Eijk, R.P.A.; Notermans, N.C. Usefulness of a Double-Blind PlaceboControlled Response Test to Demonstrate Rapid Onset Analgesia with Phenytoin 10\% Cream in Polyneuropathy. J. Pain Res. 2020, 13, 877-882. [CrossRef]

117. Zhu, W.; Li, T.; Silva, J.R.; Chen, J. Conservation and divergence in NaChBac and NaV1.7 pharmacology reveals novel drug interaction mechanisms. Sci. Rep. 2020, 10, 10730. [CrossRef]

118. Kern, K.U.; Weiser, T. Topical ambroxol for the treatment of neuropathic pain. An initial clinical observation. Schmerz 2015, 29, S89-S96. [CrossRef]

119. Pancrazio, J.J.; Kamatchi, G.L.; Roscoe, A.K.; Lynch, C., 3rd. Inhibition of neuronal Na+ channels by antidepressant drugs. J. Pharmacol. Exp. Ther. 1998, 284, 208-214.

120. Obata, H. Analgesic Mechanisms of Antidepressants for Neuropathic Pain. Int. J. Mol. Sci. 2017, 18, 2483. [CrossRef]

121. Thompson, D.; Brooks, K.G. Systematic review of topical amitriptyline for the treatment of neuropathic pain. J. Clin. Pharm. Ther. 2015, 40, 496-503. [CrossRef]

122. Price, N.; Namdari, R.; Neville, J.; Proctor, K.J.; Kaber, S.; Vest, J.; Fetell, M.; Malamut, R.; Sherrington, R.P.; Pimstone, S.N.; et al. Safety and Efficacy of a Topical Sodium Channel Inhibitor (TV-45070) in Patients With Postherpetic Neuralgia (PHN): A Randomized, Controlled, Proof-of-Concept, Crossover Study, With a Subgroup Analysis of the Nav1.7 R1150W Genotype. Clin. J. Pain 2017, 33, 310-318. [CrossRef] [PubMed]

123. Kumamoto, E. Inhibition of Fast Nerve Conduction Produced by Analgesics and Analgesic Adjuvants-Possible Involvement in Pain Alleviation. Pharmaceuticals (Basel) 2020, 13, 62. [CrossRef] [PubMed]

124. Dai, Y. TRPs and pain. Semin Immunopathol. 2016, 38, 277e91. [CrossRef]

125. Frias, B.; Merighi, A. Capsaicin, Nociception and Pain. Molecules 2016, 21, 797. [CrossRef] [PubMed]

126. Sharma, S.K.; Vij, A.S.; Sharma, M. Mechanisms and clinical uses of capsaicin. Eur. J. Pharmacol. 2013, 720, 55-62. [CrossRef] [PubMed]

127. Derry, S.; Rice, A.S.; Cole, P.; Tan, T.; Moore, R.A. Topical capsaicin (high concentration) for chronic neuropathic pain in adults. Cochrane Database Syst. Rev. 2017, 13, CD007393. [CrossRef] [PubMed]

128. Nozadze, I.; Tsiklauri, N.; Gurtskaia, G.; Tsagareli, M.G. NSAIDs attenuate hyperalgesia induced by TRP channel activation. Data Brief. 2016, 6, 668-673. [CrossRef] [PubMed]

129. Kumamoto, J.; Goto, M.; Denda, S.; Nakatani, M.; Takasugi, Y.; Tsuchiya, K.; Shimizu, Y.; Takatsuru, Y.; Denda, M. External negative electric potential accelerates exocytosis of lamellar bodies in human skin ex vivo. Exp. Dermatol. 2013, 22, 421-423. [CrossRef]

130. Kawabata, A. Targeting Ca(v)3.2 T-type calcium channels as a therapeutic strategy for chemotherapy-induced neuropathic pain. Nihon Yakurigaku Zasshi. 2013, 141, 81-84. [CrossRef]

131. Todorovic, S.M.; Jevtovic-Todorovic, V. Targeting of CaV3.2 T-type calcium channels in peripheral sensory neurons for the treatment of painful diabetic neuropathy. Pflug. Arch. 2014, 466, 701-706. [CrossRef]

132. Hiom, S.; Patel, G.K.; Newcombe, R.G.; Khot, S.; Martin, C. Severe postherpetic neuralgia and other neuropathic pain syndromes alleviated by topical gabapentin. Br. J. Dermatol. 2015, 173, 300-302. [CrossRef] [PubMed]

133. Oyama, Y.; Sadoshima, J.; Tokutomi, N.; Akaike, N. Some properties of inhibitory action of lidocaine on the Ca2p current of single isolated frog sensory neurons. Brain Res. 1988, 442, 223e8. [CrossRef]

134. Woolf, C.J.; Thompson, S.W.N. The induction and maintenance of central sensitization is dependent on N-methyl-D aspartic acid receptor activation; implications for the treatment of post-injury pain hypersensitivity states. Pain 1991, 44, 293-299. [CrossRef]

135. Jang, J.H.; Nam, T.S.; Jun, J.; Jung, S.J.; Kim, D.W.; Leem, J.W. Peripheral NMDA Receptors Mediate Antidromic Nerve Stimulation-Induced Tactile Hypersensitivity in the Rat. Mediat. Inflamm. 2015, 2015, 793624. [CrossRef] [PubMed]

136. Warncke, T.; Jørum, E.; Stubhaug, A. Local treatment with the N-methyl-d-aspartate receptor antagonist ketamine, inhibit development of secondary hyperalgesia in man by a peripheral action. Neurosci. Lett. 1997, 227, 1-4. [CrossRef]

137. Morhenn, V.B.; Murakami, M.; O'Grady, T.; Nordberg, J.; Gallo, R.L. Characterization of the expression and function of N-methylD-aspartate receptor in keratinocytes. Exp. Dermatol. 2004, 13, 505-511. [CrossRef] [PubMed]

138. Kopsky, D.J.; Keppel Hesselink, J.M.; Bhaskar, A.; Hariton, G.; Romanenko, V.; Casale, R. Analgesic effects of topical ketamine. Minerva Anestesiol. 2015, 81, 440-449.

139. Sawynok, J.; Zinger, C. Topical amitriptyline and ketamine for post-herpetic neuralgia and other forms of neuropathic pain. Expert Opin. Pharmacother. 2016, 17, 601-609. [CrossRef]

140. Mahoney, J.M.; Vardaxis, V.; Moore, J.L.; Hall, A.M.; Haffner, K.E.; Peterson, M.C. Topical ketamine cream in the treatment of painful diabetic neuropathy: A randomized, placebo-controlled, double blind initial study. J. Am. Pediatr. Med. Assoc. 2012, 102, 178-183. [CrossRef]

141. Barygin, O.I.; Nagaeva, E.I.; Tikhonov, D.B.; Belinskaya, D.A.; Vanchakova, N.P.; Shestakova, N.N. Inhibition of the NMDA and AMPA receptor channels by antidepressants and antipsychotics. Brain Res. 2017, 1660, 58-66. [CrossRef]

142. Dong, X.D.; Svensson, P.; Cairns, B.E. The analgesic action of topical diclofenac may be mediated through peripheral NMDA receptor antagonism. Pain 2009, 147, 36-45. [CrossRef] [PubMed] 
143. Heijnen, C.J.; Rouppe van der Voort, C.; van de Pol, M.; Kavelaars, A. Cytokines regulate alpha(1)-adrenergic receptor mRNA expression in human monocytic cells and endothelial cells. J. Neuroimmunol. 2002, 125, 66-72. [CrossRef]

144. Drummond, E.S.; Maker, G.; Birklein, F.; Finch, P.M.; Drummond, P.D. Topical prazosin attenuates sensitivity to tactile stimuli in patients with complex regional pain syndrome. Eur. J. Pain 2016, 20, 926-935. [CrossRef] [PubMed]

145. Yokogawa, F.; Kiuchi, Y.; Ishikawa, Y.; Otsuka, N.; Masuda, Y.; Oguchi, K.; Hosoyamada, A. An investigation of monoamine receptors involved in antinociceptive effects of antidepressants. Anesth. Analg. 2002, 95, 163-168. [CrossRef] [PubMed]

146. Ahmed, S.U.; Zhang, Y.; Chen, L.; Cohen, A.; Hillary, K.S.; Vo, T.; Houghton, M.; Mao, J. Effect of $1.5 \%$ topical diclofenac on clinical neuropathic pain. Anaesthesiology 2015, 123, 191-198. [CrossRef] [PubMed]

147. Derry, S.; Wiffen, P.J.; Kalso, E.A.; Bell, R.F.; Aldington, D.; Phillips, T.; Gaskell, H.; Moore, R.A. Topical analgesics for acute and chronic pain in adults-an overview of Cochrane Reviews. Cochrane Database Syst. Rev. 2017, 5, CD008609. [CrossRef] [PubMed]

148. Antonucci, F.; Rossi, C.; Gianfranceschi, L.; Rossetto, O.; Caleo, M. Long-distance retrograde effects of botulinum neurotoxin A. J. Neurosci. 2008, 28, 3689-3696. [CrossRef] [PubMed]

149. Marinelli, S.; Luvisetto, S.; Cobianchi, S.; Makuch, W.; Obara, I.; Mezzaroma, E.; Caruso, M.; Straface, E.; Przewlocka, B.; Pavone, F. Botulinum neurotoxin type A counteracts neuropathic pain and facilitates functional recovery after peripheral nerve injury in animal models. Neuroscience 2010, 171, 316-328. [CrossRef]

150. Mika, J.; Rojewska, E.; Makuch, W.; Korostynski, M.; Luvisetto, S.; Marinelli, S.; Pavone, F.; Przewlocka, B. The effect of botulinum neurotoxin A on sciatic nerve injury-induced neuroimmunological changes in rat dorsal root ganglia and spinal cord. Neuroscience 2011, 175, 358-366. [CrossRef]

151. Luvisetto, S.; Marinelli, S.; Lucchetti, F.; Marchi, F.; Cobianchi, S.; Rossetto, O.; Montecucco, C.; Pavone, F. Botulinum neurotoxins and formalin-induced pain: Central vs. peripheral effects in mice. Brain Res. 2006, 1082, 124-131. [CrossRef]

152. Ngo, D.H.; Vo, T.S. An Updated Review on Pharmaceutical Properties of Gamma-Aminobutyric Acid. Molecules 2019, $24,2678$. [CrossRef] [PubMed]

153. Wu, C.; Qin, X.; Du, H.; Li, N.; Ren, W.; Peng, Y. The immunological function of GABAergic system. Front. Biosci. (Landmark Ed). 2017, 1, 1162-1172.

154. Whitehead, R.A.; Puil, E.; Ries, C.R.; Schwarz, S.K.; Wall, R.A.; Cooke, J.E.; Putrenko, I.; Sallam, N.A.; MacLeod, B.A. GABA(B) receptor-mediated selective peripheral analgesia by the non-proteinogenic amino acid, isovaline. Neuroscience 2012, 213, 154-160. [CrossRef] [PubMed]

155. Kopsky, D.J.; Hesselink, J.M.K. Neuropathic pain as a result of acromegaly, treated with topical baclofen cream. J. Pain Symptom. Manag. 2013, 46, e4-e5. [CrossRef] [PubMed]

156. Barton, D.L.; Wos, E.J.; Qin, R.; Mattar, B.I.; Green, N.B.; Lanier, K.S.; Bearden, J.D., 3rd; Kugler, J.W.; Hoff, K.L.; Reddy, P.S.; et al. A double-blind, placebo-controlled trial of a topical treatment for chemotherapy-induced peripheral neuropathy: NCCTG trial N06CA. Support Care Cancer 2011, 19, 833-841. [CrossRef]

157. McCarson, K.E.; Duric, V.; Reisman, S.A.; Winter, M.; Enna, S.J. GABA(B) receptor function and subunit expression in the rat spinal cord as indicators of stress and the antinociceptive response to antidepressants. Brain Res. 2006, 1068, 109-117. [CrossRef]

158. Irifune, M.; Sato, T.; Kamata, Y.; Nishikawa, T.; Dohi, T.; Kawahara, M. Evidence for GABA(A) receptor agonistic properties of ketamine: Convulsive and anesthetic behavioral models in mice. Anesth. Analg. 2000, 91, 230-236.

159. Granger, P.; Biton, B.; Faure, C.; Vige, X.; Depoortere, H.; Graham, D.; Langer, S.Z.; Scatton, B.; Avenet, P. Modulation of the gamma-aminobutyric acid type A receptor by the antiepileptic drugs carbamazepine and phenytoin. Mol. Pharmacol. 1995, 47, 1189-1196.

160. Buerkle, H. Peripheral antinociceptive action of alpha2- adrenoceptor agonist. Baillières Clin. Anaesthesiol. 2000, 2, 411-418.

161. Riedl, M.S.; Schnell, S.A.; Overland, A.C.; Chabot-Doré, A.J.; Taylor, A.M.; Ribeiro-da-Silva, A.; Elde, R.P.; Wilcox, G.L.; Stone, L.S. Coexpression of alpha $2 \mathrm{~A}$-adrenergic and delta-opioid receptors in substance P-containing terminals in rat dorsal horn. J. Comp. Neurol. 2009, 513, 385-398. [CrossRef]

162. Shi, T.S.; Winzer-Serhan, U.; Leslie, F.; Hokfelt, T. Distribution and regulation of alpha(2)-adrenoceptors in rat dorsal root ganglia. Pain 2000, 84, 319-330. [CrossRef]

163. Kawasaki, T.; Kawasaki, C.; Ueki, M.; Hamada, K.; Habe, K.; Sata, T. Dexmedetomidine suppresses proinflammatory mediator production in human whole blood in vitro. J. Trauma Acute Care Surg. 2013, 74, 1370-1375. [CrossRef] [PubMed]

164. Wrzosek, A.; Woron, J.; Dobrogowski, J.; Jakowicka-Wordliczek, J.; Wordliczek, J. Topical clonidine for neuropathic pain (review). Cochrane Database Syst. Rev. 2015, 8, CD010967. [PubMed]

165. Obara, I.; Parkitna, J.R.; Korostynski, M.; Makuch, W.; Kaminska, D.; Przewlocka, B.; Przewlocki, R. Local peripheral opioid effects and expression of opioid genes in the spinal cord and dorsal root ganglia in neuropathic and inflammatory pain. Pain 2009, 141, 283-291. [CrossRef] [PubMed]

166. Machelska, H.; Celik, M.Ö. Opioid Receptors in Immune and Glial Cells-Implications for Pain Control. Front Immunol. 2020, 11, 300. [CrossRef] [PubMed]

167. Bigliardi-Qi, M.; Sumanovski, L.T.; Büchner, S.; Rufli, T.; Bigliardi, P.L. Mu-opiate receptor and Beta-endorphin expression in nerve endings and keratinocytes in human skin. Dermatology 2004, 209, 183-189. [CrossRef] [PubMed]

168. Tiwari, V.; Anderson, M.; Yang, F.; Tiwari, V.; Zheng, Q.; He, S.Q.; Zhang, T.; Shu, B.; Chen, X.; Grenald, S.A.; et al. Peripherally acting $\mathrm{m}$-opioid receptor agonists attenuate ongoing pain-associated behavior and spontaneous neuronal activity after nerve injury in rats. Anesthesiology 2018, 128, 1220-1236. [CrossRef] 
169. Kopsky, D.J.; Bhaskar, A.K.; Zonneveldt, H.J.; Keppel Hesselink, J.M. Topical loperamide for the treatment of localized neuropathic pain: A case report and literature review. J. Pain Res. 2019, 12, 1189-1192. [CrossRef]

170. Ciałkowska-Rysz, A.; Dzierżanowski, T. Topical morphine for treatment of cancer-related painful mucosal and cutaneous lesions: A double-blind, placebo-controlled cross-over clinical trial. Arch. Med. Sci. 2019, 15, 146-151. [CrossRef]

171. Maldonado, R.; Banos, J.E.; Cabanero, D. The endocannabinoid system and neuropathic pain. Pain 2016, 157, S23-S32. [CrossRef]

172. Lötsch, J.; Weyer-Menkhoff, I.; Tegeder, I. Current evidence of cannabinoid-based analgesia obtained in preclinical and human experimental settings. Eur. J. Pain 2018, 22, 471-484. [CrossRef] [PubMed]

173. Bruni, N.; Della Pepa, C.; Oliaro-Bosso, S.; Pessione, E.; Gastaldi, D.; Dosio, F. Cannabinoid Delivery Systems for Pain and Inflammation Treatment. Molecules 2018, 23, 2478. [CrossRef] [PubMed]

174. Keppel Hesselink, J.M.; Kopsky, D.J.; Sajben, N. New topical treatment of vulvodynia based on the pathogenetic role of cross talk between nociceptors, immunocompetent cells, and epithelial cells. J. Pain Res. 2016, 9, 757-762. [CrossRef] [PubMed] 